$51 \mid 2020$

Ladakh Through the Ages. A Volume on Art History and Archaeology, followed by Varia

\title{
Buddhism before the First Diffusion? The case of Tangol, Dras, Phikhar and Sani-Tarungtse in Purig and Zanskar (Ladakh)
}

Le bouddhisme avant la Première Diffusion? Les cas de Tangol, Dras, Phikhar et Sani-Tarungtse au Purig et au Zanskar (Ladakh)

\section{Quentin Devers}

\section{(2) OpenEdition}

Journals

\section{Electronic version}

URL: https://journals.openedition.org/emscat/4226

DOI: $10.4000 /$ emscat.4226

ISSN: 2101-0013

\section{Publisher}

Centre d'Etudes Mongoles \& Sibériennes / École Pratique des Hautes Études

\section{Electronic reference}

Quentin Devers, "Buddhism before the First Diffusion? The case of Tangol, Dras, Phikhar and SaniTarungtse in Purig and Zanskar (Ladakh)", Études mongoles et sibériennes, centrasiatiques et tibétaines [Online], 51 | 2020, Online since 09 December 2020, connection on 13 July 2021. URL: http:// journals.openedition.org/emscat/4226 ; DOI: https://doi.org/10.4000/emscat.4226

This text was automatically generated on 13 July 2021.

(c) Tous droits réservés 


\title{
Buddhism before the First Diffusion? The case of Tangol, Dras, Phikhar and Sani-Tarungtse in Purig and Zanskar (Ladakh)
}

\author{
Le bouddhisme avant la Première Diffusion? Les cas de Tangol, Dras, Phikhar et \\ Sani-Tarungtse au Purig et au Zanskar (Ladakh)
}

Quentin Devers

\section{Introduction}

The purpose of this paper is to introduce newly documented sites from Purig and Zanskar that offer a rare insight into an early phase of Buddhism in Ladakh of Central Asian or Kashmiri inspiration. The question of the introduction of Buddhism to Ladakh is usually tied to the Great Translator Rinchen Zangpo (Tib. rin chen bzang po). This prominent figure of the so-called Second Diffusion in the late $10^{\text {th }}$ to early $11^{\text {th }}$ century is locally believed to have single-handedly introduced Buddhism to the region. The first monastery is thus supposed to be the "sacred compound" (choskhor; Tib. chos 'khor) built by Rinchen Zangpo in Nyarma ${ }^{1}$ at the turn of the $11^{\text {th }}$ century. This popular tradition is however in contradiction with the numerous stories surrounding caves where the $8^{\text {th }}$ century Buddhist master Guru Rinpoche (Tib. gu ru rin po che, Padmasambhava) is believed to have meditated, and which can be found in various parts of the region. This paradox has resulted in a strange divide of the religious structures of Ladakh: ancient temples are commonly attributed to Rinchen Zangpo, while ancient caves are commonly attributed to Guru Rinpoche. At any rate, both Guru Rinpoche and Rinchen Zangpo are associated with the spread of Buddhism from a Tibetan perspective, with the so-called First and Second Diffusions. 
Oral tradition aside, very little research has been carried out on the topic of the introduction of Buddhism to Ladakh until recently. The only sites to be studied were those dating from the $10^{\text {th }}$ to $15^{\text {th }}$ century such as Nyarma, Basgo, Alchi, Mangyu, Sumda, Wanla, Saspol, Lamayuru, etc. An important step forward took place in 2011, when a rather atypical stupa complex was documented in Tirisa (Nubra, fig. 1) during surveys conducted by Martin Vernier, Laurianne Bruneau, and myself (fig. 2). It consists of a large stupa of the Descent from Heaven type, nearly $10 \mathrm{~m}$ in height, set on a quadrangular platform about $25 \times 25 \mathrm{~m}$ and surrounded by an enclosure. This type of complex is rather alien to Ladakh, but is well documented in Central Asia and Kashmir during the last quarter of the first millennium CE (Bruneau 2013, p. 19).

The complex was the object of more in-depth research in 2013 in the context of the Indo-French Archaeological Mission in Ladakh, co-directed by Simatri B. Ota and Laurianne Bruneau. $\mathrm{C}^{14}$-dating of two samples confirmed the date proposed by Bruneau in her initial assessment ${ }^{2}$. Although this discovery does not necessarily indicate a presence of Buddhism before Guru Rinpoche's time, it did open new perspectives for the study of the history of Buddhism in the region, as there appears to have been Buddhism of Central Asian or Kashmiri inspiration not derived from the First or Second Diffusion of Buddhism to Tibet.

During the summer of 2016, I carried out a comprehensive survey of historical sites in Purig in collaboration with Kacho Mumtaz Khan for the Indian National Trust for Art and Cultural Heritage (INTACH). In the course of this fieldwork, I came across three sites $^{3}$ (in Tangol, Dras and Phikhar, see figs 1,3 ) that caused me to reconsider the general chronology of Buddhism in Ladakh. To these three sites a fourth may be added, located in Zanskar, above the village of Tarungtse (or Tagluntse) near Sani ${ }^{4}$ (see map, fig. 1). Though I had already visited it in 2011 based on descriptions published by Francke and Howard (Francke 1906, p. 650; Howard 1995, pp. 82-83), it was only during a new survey carried out together with Samara Broglia de Moura in the summer of 2017 that I obtained a new understanding of the site, largely attributable to the discoveries made by Samara during this season (see her article in the present volume). All four sites are locally referred to as Khar (Tib. mkhar) or fortifications. However, based on the corpus of over 370 fortified sites all over Ladakh that I have built up over the years, I can positively assert that these sites do not look like any of the other forts that I have come across. On the other hand, their plans do evoke monasteries of Central Asian or Kashmiri types. Let us now review the data and see what it means for the history of the region. 
Figure 1. Location of the sites under review (stars), main towns (squares), and places mentioned in the text (circles)

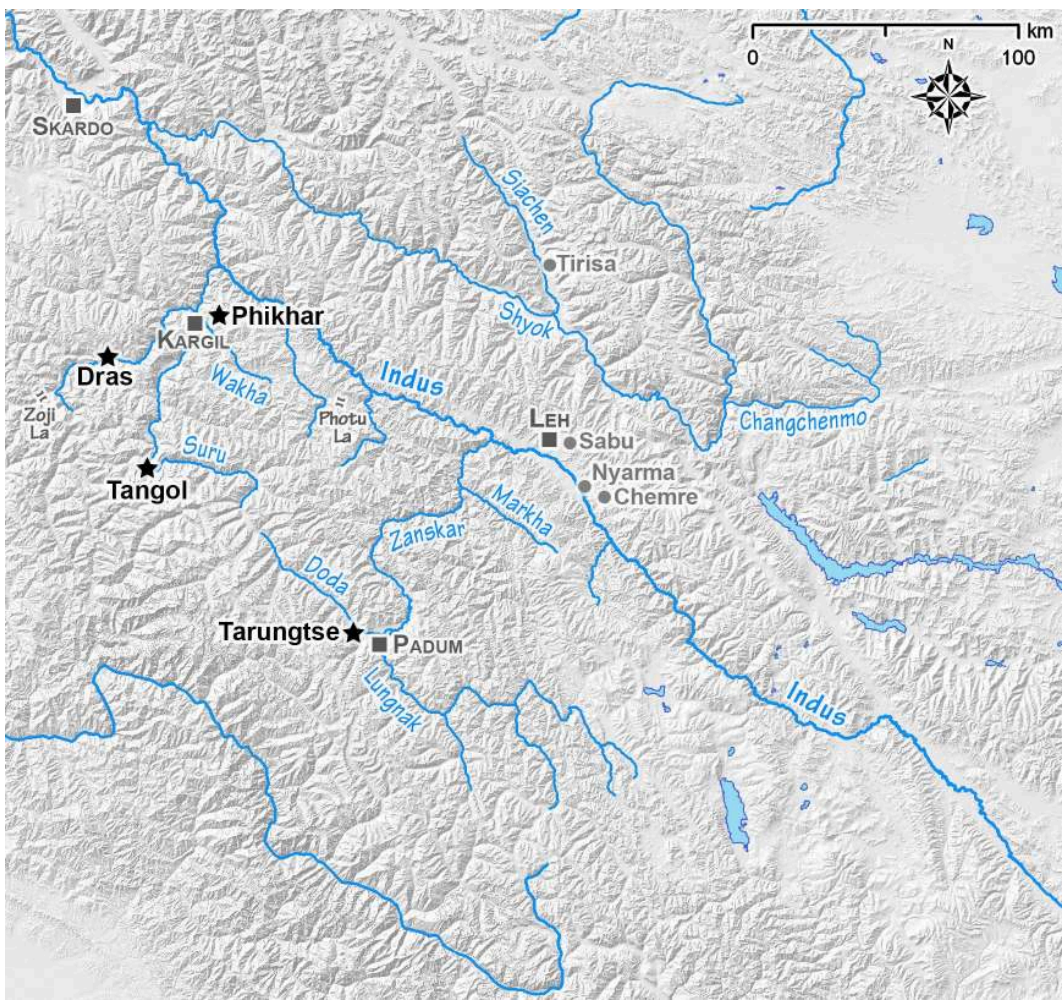

(c) Quentin Devers, 2017

Figure 2. General view of Tirisa stupa from the south

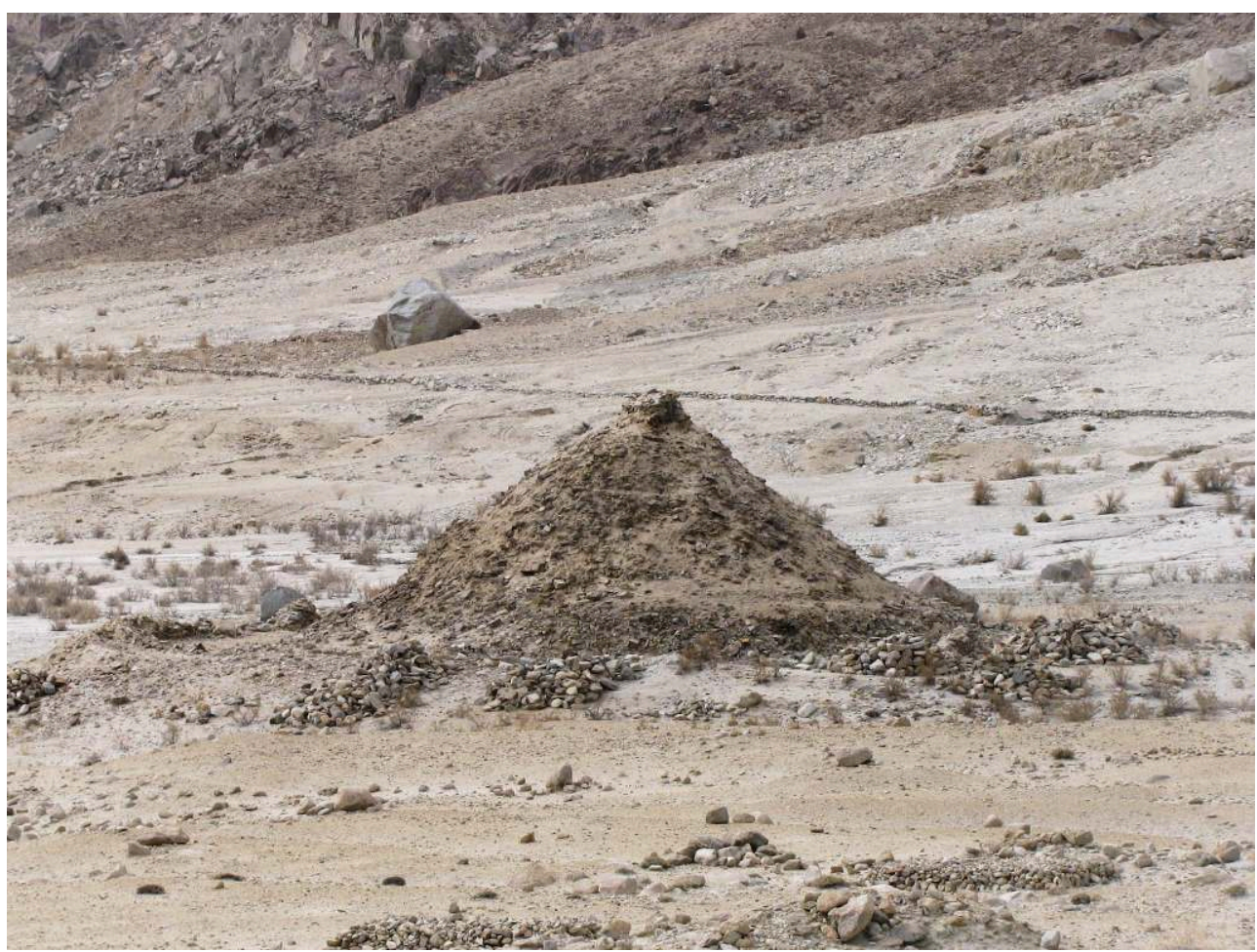

(c) Quentin Devers, 2011 
Figure 3. Map of Purig with the sites under review (stars), district capital (square), and places mentioned in the text (circles)

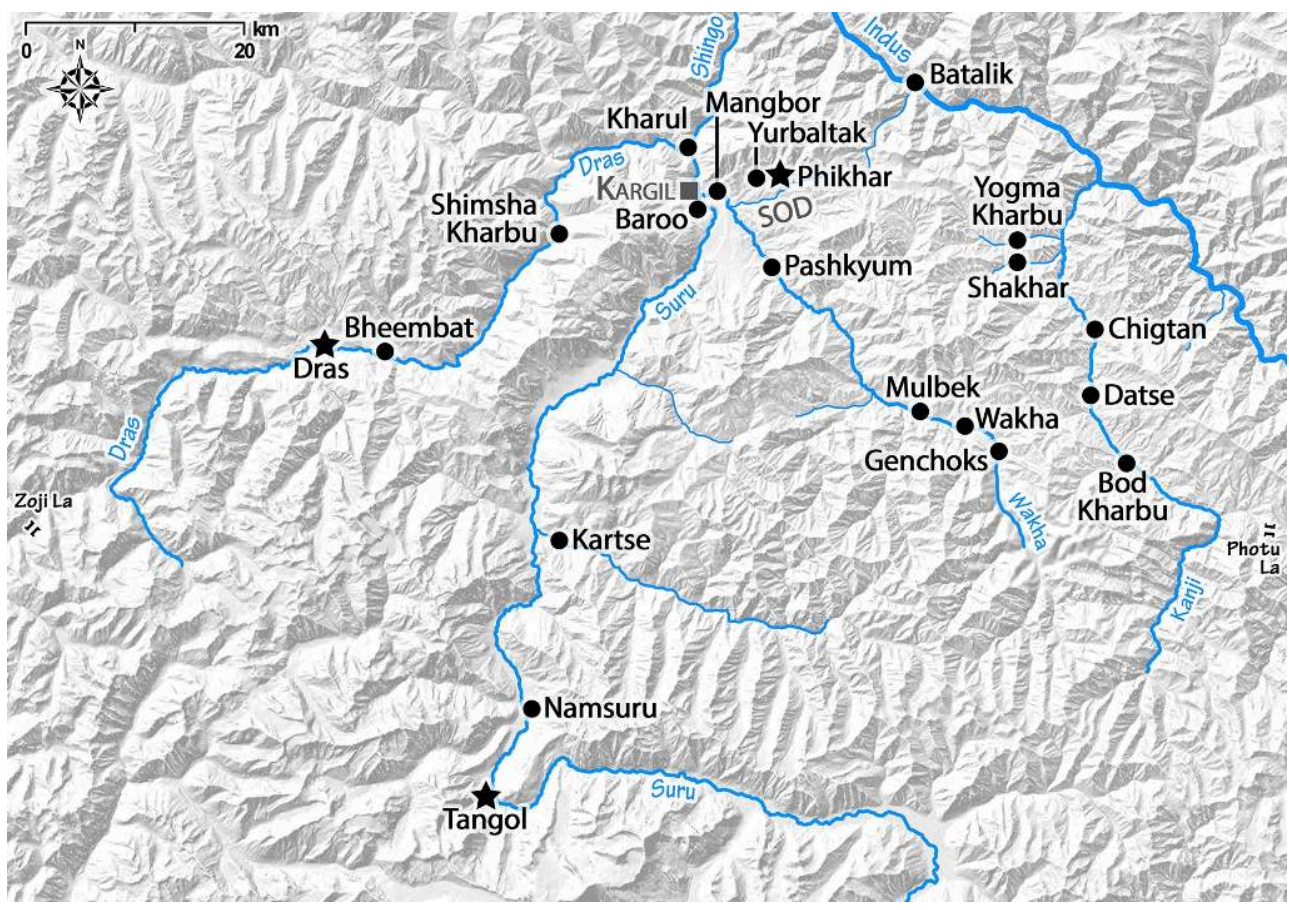

(C) Quentin Devers, 2017

\section{Dras and the south Suru valley. Archaeological and historical context}

Before we look at the sites themselves, it is important to consider the archaeological and historical contexts of Dras and the south Suru valley (south of Khartse). Purig, the region locally referred to as "Kargil" in present Ladakh, extends from the Photu La (pass) above Lamayuru to the Zoji La, which marks the border with Kashmir (figs 1, 3). Purig is the least studied region of Ladakh, having been mostly disregarded by modern research. It is, however, a crucial region for the understanding of the region's complex past. For instance, whereas Purig accounts for only about $10 \%$ of Ladakh's territory, over $20 \%$ of the $370+$ fortifications documented so far are located there. Purig also accounts for about $15 \%$ of the nearly 400 known rock art sites.

Purig is not a uniform region. A geographical analysis of the material remains shows a clear territorial differentiation over time. In particular, Dras and the south Suru valley stand out by the Kashmiri influence that can be seen in their remains. Both hold a similar geographical situation, in the sense that they are the starting points of the only routes leading to Kashmir. In modern times, they are the only parts of Purig with pockets of Sunni populations $s^{5}$ in an otherwise entirely Shia and Noorbakshia region. This is the result of Kashmiri influence in these two places that can be traced at various moments in the past. We will for that matter focus mainly on Dras, for which more data are available.

7 In 1820, Moorcroft noted that "the lands of Dras are the joint property of the Raja of Ladakh and "chief landholder" (Malik) ${ }^{6}$ of the neighbouring part of Kashmir", each 
imposing a tax of one rupee plus some grain per year and per household (Moorcroft \& Trebeck 1841, p. 41$)$. Going back in time, in the late $14^{\text {th }}$ or early $15^{\text {th }}$ century, an inscription inside the Nyima Lhakhang in Mulbek tells us that the king of Phokhar, having conquered Mulbek, Wakha, Stagtse and Bod Kharbu, was given the village of Kharool by the king of Kashmir (Martin 2015). As Kharool is the village at the mouth of the Dras valley, this suggests that the whole Dras valley was under Kashmiri administration then. The commemorative inscription on the famous Buddhist carvings at Dras, which were made between the $8^{\text {th }}$ and the $12^{\text {th }}$ century, was written in Sarada, the ancient script of Kashmir. These are the only Buddhist carvings with such inscriptions - everywhere else in Ladakh, inscriptions on Buddhist carvings are written in Tibetan ${ }^{7}$.

8 During joint fieldwork with Samara Broglia de Moura in the summer of 2017, I was astonished that she could identify Kushan and post-Kushan ceramics in four of the many fortifications found in Dras. Dras and the south Suru valley are also the only parts of Purig without fortifications attributed to the Dards, and they also lack the elaborate petroglyphs that are otherwise so common in the rest of Purig and in the lower Indus valley of Ladakh ${ }^{8}$. All this strongly hints at a fundamentally different ancient past compared to the other areas in Ladakh.

9 Finally, both places are the only ones in Ladakh with forts named Biru Khar. This point may seem quite trivial, but names of forts are usually very easy to understand in Ladakh. Fortifications are commonly named after the topographies they are built on', after geographical situations ${ }^{10}$, after specific stories linked to their locations ${ }^{11}$, or after the populations that are thought to have built them ${ }^{12}$; some have poetic names like Mentok Khar or "the flower fort"13. There are, however, instances where names reflect non-Tibetan origins, and Biru Khar is one of them. It is only encountered in Dras, Bheembat (near Dras) and Namsuru (south Suru valley), which are the starting points of the only routes leading to Kashmir, and where influence from Kashmir can be traced throughout history.

It also needs to be remembered that Purig is the region where in more recent times, around the $15^{\text {th }}$ or $16^{\text {th }}$ centuries, the introduction of a new religion, Islam, took place. This religion has been coming from two main directions: the north-western Pamir corridor (through Gilgit and Baltistan), and Kashmir. The same regions were among the most prominent places for Buddhism in the past.

11 Bearing in mind that significant cultural and material influence from Kashmir can be traced in Dras and in the south Suru area throughout history, and that Purig once was at the forefront of the introduction of a major religion to Ladakh, we can properly look at the ruins found there.

\section{Tangol (south Suru valley)}


Figure 4. General view of Tangol's remains from the southeast: the main ruins are on the tip of the ridge (B), preceded by a secondary structure $(A)$

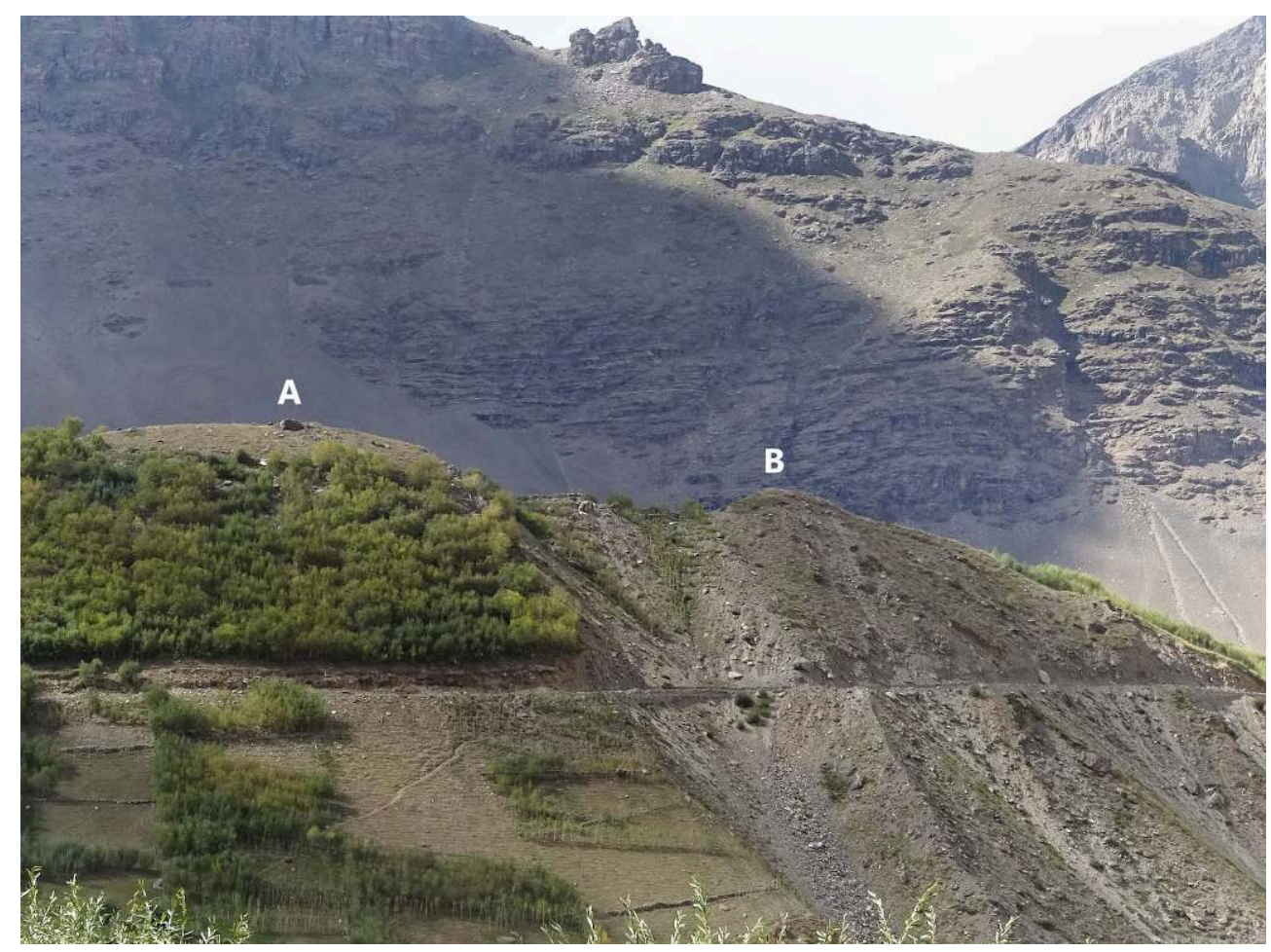

(C) Quentin Devers, 2016

\section{The remains}

12 The ruins are located in a part of Tangol known as "Gonpa". The site is located on the tip of a narrow ridge (fig. 4). A platform is built on the topmost part of the hilltop, from where two rows of small rooms follow the edge of the topography (figs 5-7). These rooms thus delineate a central courtyard. Although the topography is used in a typical defensive fashion, several architectural elements argue against the identification of the site as a fortification. 
Figure 5. View of the main ruins from the platform at the southern end of the site

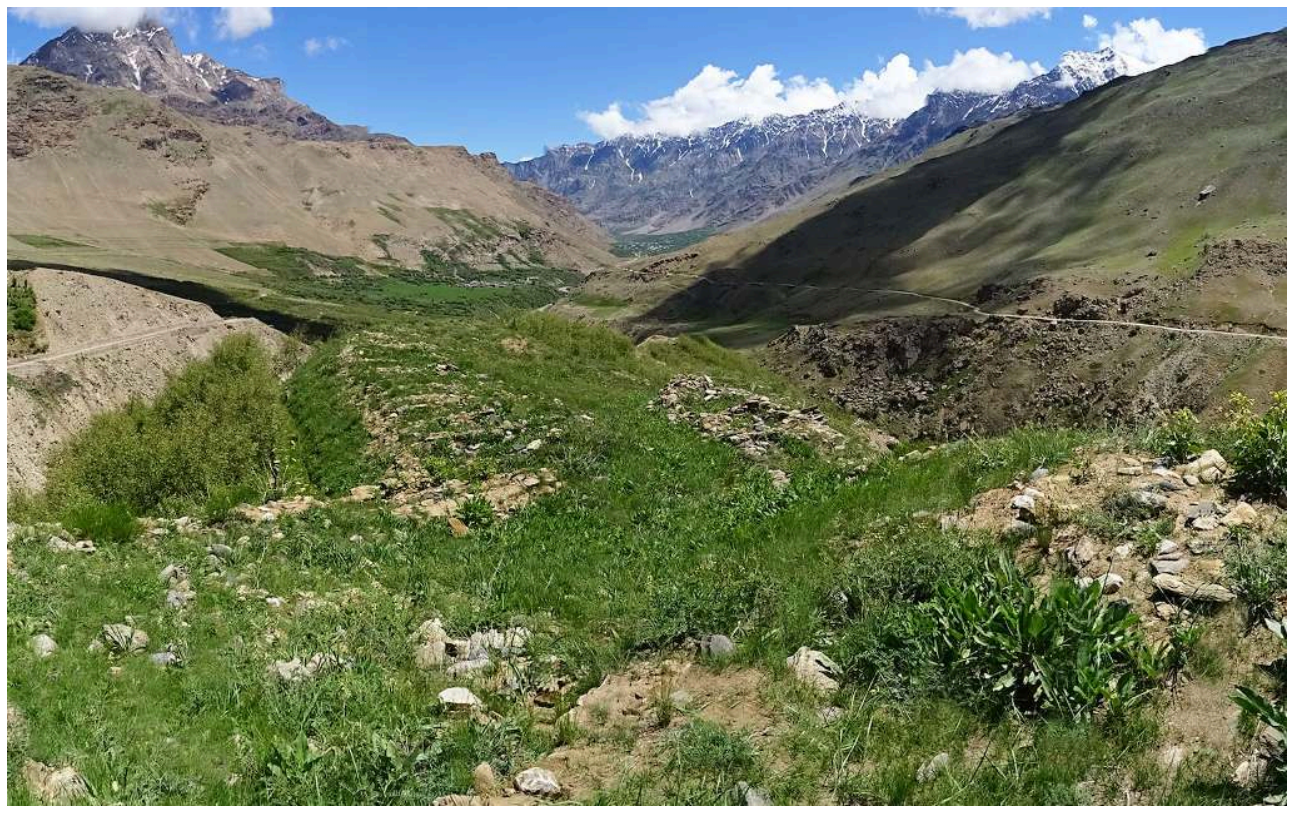

(c) Quentin Devers, 2017

Figure 6. Plan of the main ruins of Tangol

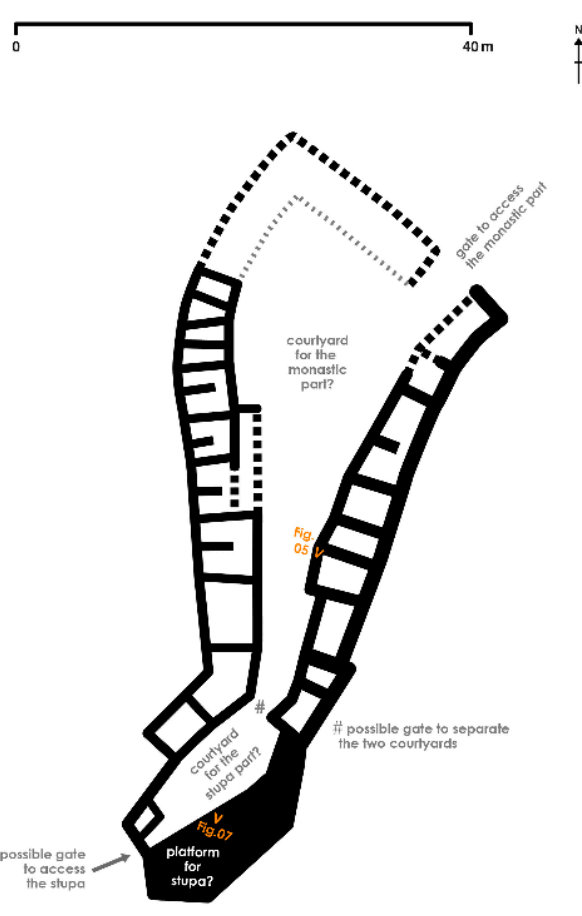

(c) Quentin Devers, 2017 
Figure 7. Detailed view of the eastern row of rooms from the south

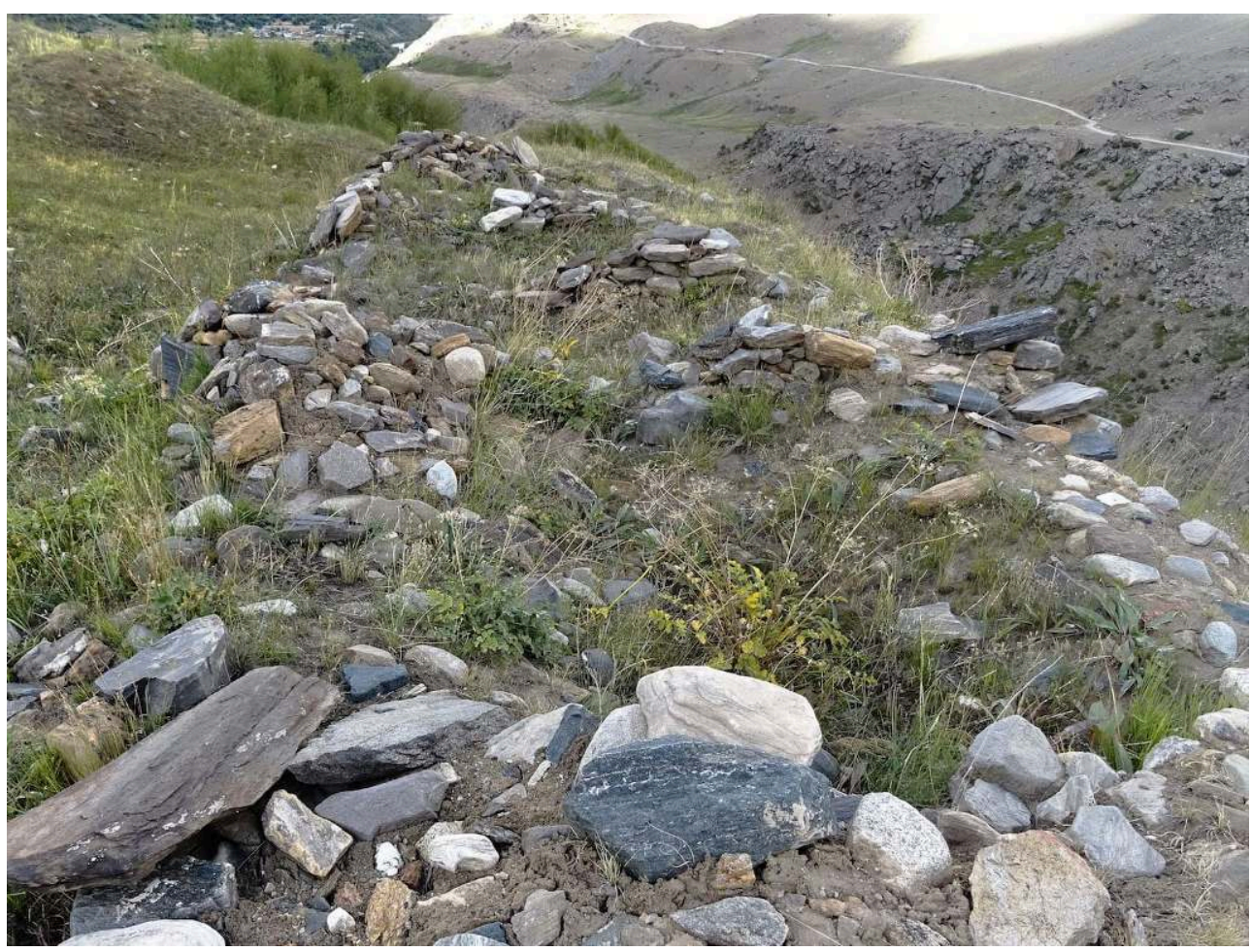

(C) Quentin Devers, 2016

13 For instance, if it was a fortification, with well over twenty rooms currently distinguishable (and probably closer to thirty originally), this site would have been a fortified settlement, not a regular fort - no fort in Ladakh counts so many rooms on the ground floor. However, the layout of the rooms shows that it could not have been a fortified settlement. Indeed, fortified settlements in Ladakh are mostly characterised by clustered buildings. Even when the settlements are built on a large plateau, the habitations are invariably clustered on one part of the topography only. The rare instances where habitations are spread along the periphery of the relief are in fortified settlements attributed to the $\mathrm{Mon}^{14}$. But even then, in addition to the habitations built along the outer edge of the site, we do find constructions in the middle of the settlement as well. Thus, nowhere in Ladakh are there fortified settlements that follow such a neat plan as in Tangol.

14 Further clues are found in the study of the walls. In regular fortified settlements, including Mon fortifications, when the outer wall is made of the contiguous walls of the habitations, these are all built against one another as separate buildings, adjacent to each other. But in Tangol adjoining rooms are separated by a single wall only, making it one large coherent building. Another element to take into account is the size of the rooms. About half the rooms are less than $2 \mathrm{~m}$ wide, and a quarter have a width of only $1,1 \mathrm{~m}$. These rooms are simply too small for use as habitation.

15 All this argues against a fortified settlement. On the other hand, a prominent platform at the end of two rows of small cells that delineate an internal courtyard fits the description of a monastery of Central Asian type. Though monasteries in Central Asia, most of the time, had quadrangular plans, one has to keep in mind that in Ladakh buildings hardly ever followed strict regular plans until quite recently. The vast 
majority of temples in Ladakh do display skewed floor plans - with the exception of very few remarkable buildings such as in Nyarma. Neat perpendicular angles and neat straight walls in architecture do not appear to have been a main preoccupation in the region for most of its history.

Reading Tangol as a monastery, we would then have a main courtyard for the monastic part, with a main gate on the northern side of the site. A secondary courtyard would be in front of the stupa, on the southern side of the site. Between the two courtyards was a narrow passage that could have been easily closed off with a gate if needed. Remains of a possible stupa are not currently visible on the platform: its existence is yet to be ascertained. On the narrow ridge behind the monastery is another platform (A in fig. 4), built in masonry of unusually large stones. This platform also does not hold remains of any superstructure, but considering how strongly it is built, a former superstructure of significant size is very likely. Given the proportions of this platform, if it was at any point used as a stupa base, it would probably have held two stupas side by side ${ }^{15}$. In summary, there could have been stupas at two locations: on the platform inside the monastery, and/or on the platform along the ridge. Finally, we could notice that the very name of this part of Tangol, "Gonpa", is suggestive of a past monastery in this area.

\section{Textual sources}

17 The site of Tangol was first surveyed by Sonam Spalzin and Sonam Phuntsog in 2014. They had been in search of a monastery mentioned in the Rajatarangini, and thought to identify it with the ruins of Tangol. In the Rajatarangini it is said that king Surendra, who was the first to build Buddhist monasteries called vihäras in Kashmir, four generations before Aśoka ( $3^{\text {rd }}$ century BCE), "founded in the neighbourhood of the Darad country a town called Soraka, and built the Vihāra called Narendrabhavana" (Rajatarangini Book I, verse 93; Stein 1900, p. 17). Ganhar and Ganhar hypothesised in 1956 that Soraka corresponded to the Suru valley in Ladakh, which was near the country of the Dards (Ganhar \& Ganhar 1956, p. 16).

There are a number of difficulties with this identification, the most important being that the first book of the Rajatarangini is notoriously unreliable, and for many of the kings mentioned there it is not clear whether they actually existed. Beyond the question of the historicity of king Surendra, we can also not ascertain whether Soraka does indeed correspond to Suru. From the southern part of the Suru valley does start the shortest route to Kashmir (60 km in a straight line from the famous pilgrimage destination of Chandanwari near Pahalgam to the Suru valley). The southern Suru valley was also historically neighbouring Dardic territories, as the several Dardattributed forts ('Brogpai Khar') found in the northern parts of the Purig region indicate. The identification of Soraka with Suru thus seems plausible, but cannot be proved at present. Beyond that, even if by any chance Soraka was indeed Suru, it is far from certain that the ruins at Tangol correspond to the monastery founded by Surendra.

19 The identification of the remains of Tangol with the foundation mentioned in the Rajatarangini seems thus rather questionable. There are, however, a number of elements to consider before rushing to exclude such identification without further research. As we will see in the next part about the Rgyalmo Khar, there is 
overwhelming material evidence in Dras of Kashmiri and Central Asian elements - Dras may well have been under Kashmiri control for important parts of its history. Also, the Biru Khar of Namsuru is set on an atypically low topography - Ladakhi forts are usually situated rather majestically high up on hills -, and this could point to a different source of inspiration for its architecture.

When I first set out for Tangol, I did not believe that it could be an actual twothousand-year old monastery, and I thought it would be easy to disprove it. When I saw the location from a distance, it just seemed to be a typical fortified settlement. However, a closer study of the remains made me realize that the site was not as simple as I initially thought, and that these could well be the ruins of a monastery from a nonTibetan form of Buddhism ${ }^{16}$. The physical analysis of the site, and the unusual material remains in the southern Suru valley and in the surroundings of Dras, call for further studies, and in particular for excavations. There is a dire need for a better understanding of the chronology of these ruins, and for determining if it was indeed a monastery and, if so, from which period.

\section{Dras: Rgyalmo Khar}

Figure 8. General view of Biru Khar (A) and Rgyalmo Khar (B) from Lhamochen Khar in the south

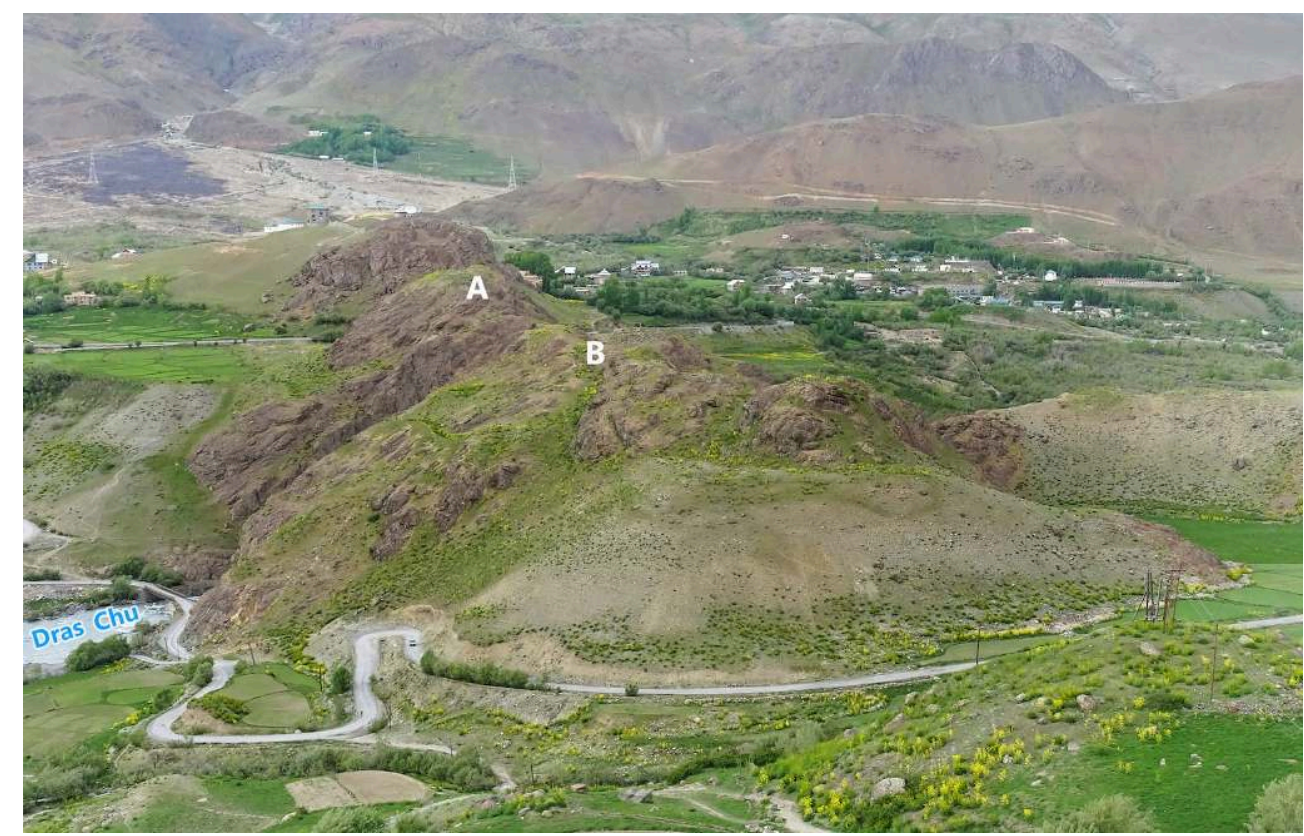

(C) Quentin Devers, 2017

\section{The remains}

Among the remains in Dras is the Rgyalmo Khar in the sub-village Suku Tial. At the outskirts of Dras, when coming from Kargil, the famous Buddhist carvings are kept in a small shelter on the left side of the road in the vicinity of the Biru Khar, a fort built on a hill bordering the Dras brook (fig. 8). Right on the other side of the stream, on the true right bank, rises another hill. These two hills are only a stone-throw's distance from 
one another, and their cliffs form a narrow gorge for the stream (fig. 9). The second hill bears the remains of the Rgyalmo Khar.

Figure 9. Gorge between Biru Khar (A) and Rgyalmo Khar (B) from the west

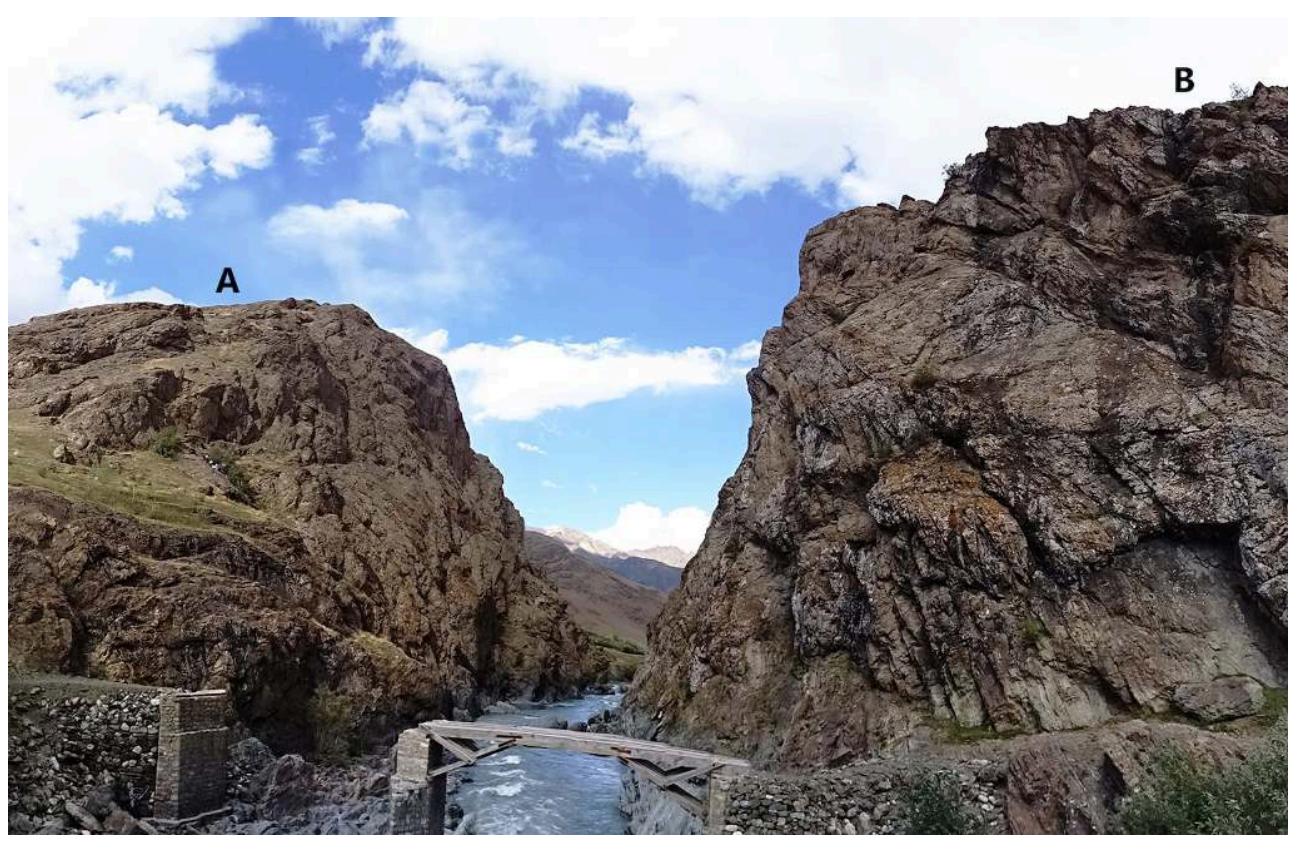

(c) Quentin Devers, 2016

Rgyalmo Khar is a more complex site than Tangol. There are structures everywhere on the hill, which in turn is significantly larger than the narrow ridge of Tangol. The possible nature of the site is as such not as straightforward to determine as in Tangol; it displays features that point to a mixed usage: defensive, and possibly monastic.

The defensive parts of the Rgyalmo Khar are found on its periphery. They consist of shallow trenches and pits (fig. 10). Such defences are very rare in Ladakh and can be seen only in another site in Dras at the Goshan Khar (fig. 11), and in Chemre at the Khyangra Khar. These features point to significantly different conceptions of defences and habits of warfare from what was usual elsewhere in Ladakh. Furthermore, during our joint surveys in 2017 Samara Broglia de Moura identified both Kushan and postKushan ceramics at Goshan Khar, making it the only site of Ladakh so far with Kushanperiod ceramics. She also identified post-Kushan pottery at the Rgyalmo Khar and at the Lhamochen Khar, another fortification located behind the Rgyalmo Khar. Dras thus stands out as the place of Ladakh with the highest concentration of Kushan and postKushan material. And two of these sites where Kushan and post-Kushan ceramics have been found have similar defences of shallow trenches and pits that are by all means foreign to Ladakh. 
Figure 10. Example of a shallow trench at Rgyalmo Khar

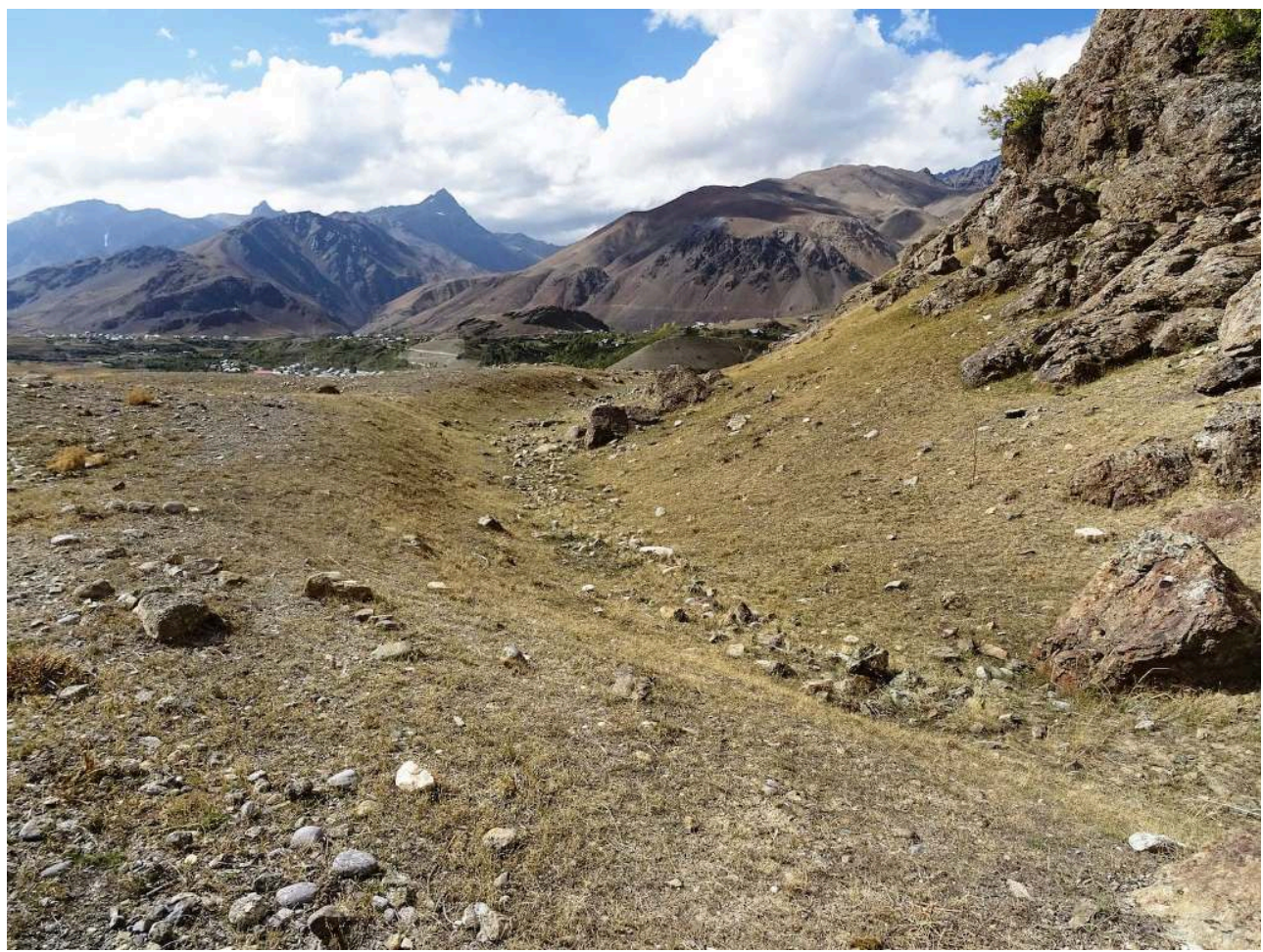

(C) Quentin Devers, 2016

Figure 11. Example of a shallow trench at Goshan Khar

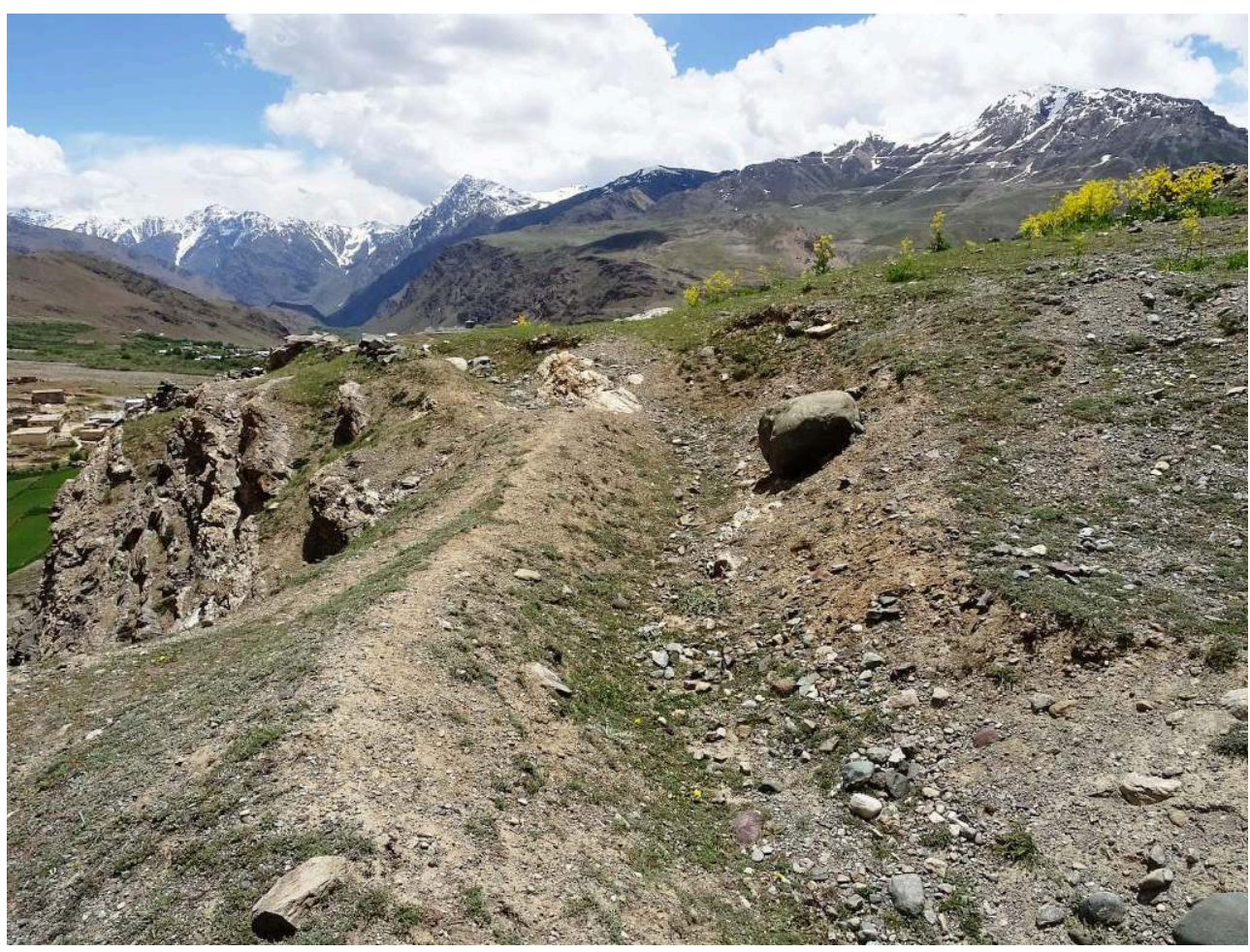

(c) Quentin Devers, 2017 
The possible monastic part of Rgyalmo Khar is found on the top-most ridge of the hill, which is doted with two small mounds: one at the northern end crowned with a large building ("1" on fig.12), and one just before the southern end topped with a quadrangular platform ("2" on fig. 12). This platform appears to have constituted the base for a superstructure, making it a good candidate for the stupa that such monastic compound would in all likelihood have had.

Figure 12. Plan of the inner compound of Rgyalmo Khar

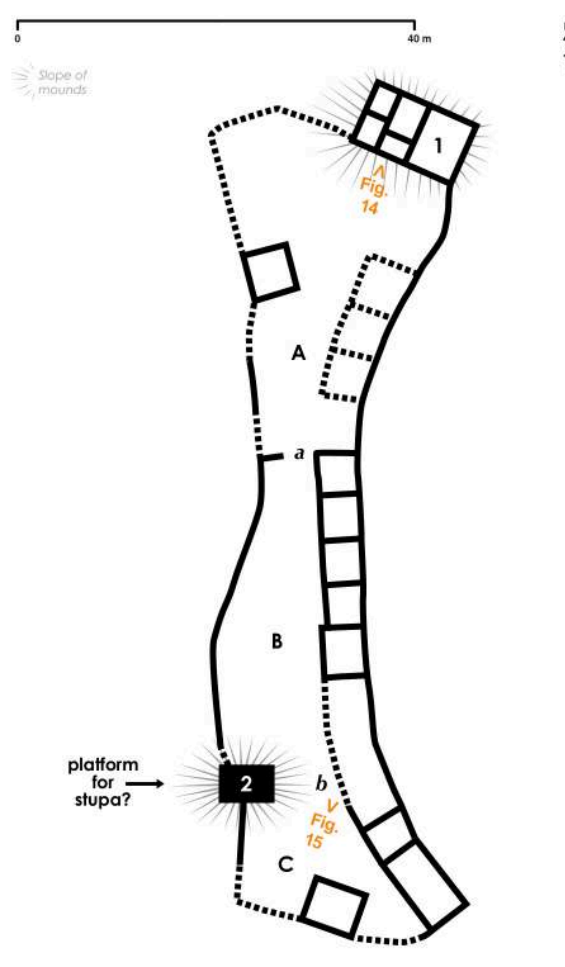

(C) Quentin Devers, 2017

The plan of the compound is fairly simple. A row of small rooms follows the edge of the ridge on the eastern side, while the western edge consists of a long wall interrupted only by a single building (figs 12-14). These structures delineate a long courtyard in the centre, that is divided in three subspaces (A to C) by a narrow passage in "a" (a wall protrudes from the western boundary wall) and in "b" (the lower edge of the mound comes very close to the eastern row of rooms). 
Figure 13. View of the inner compound from the northern mound

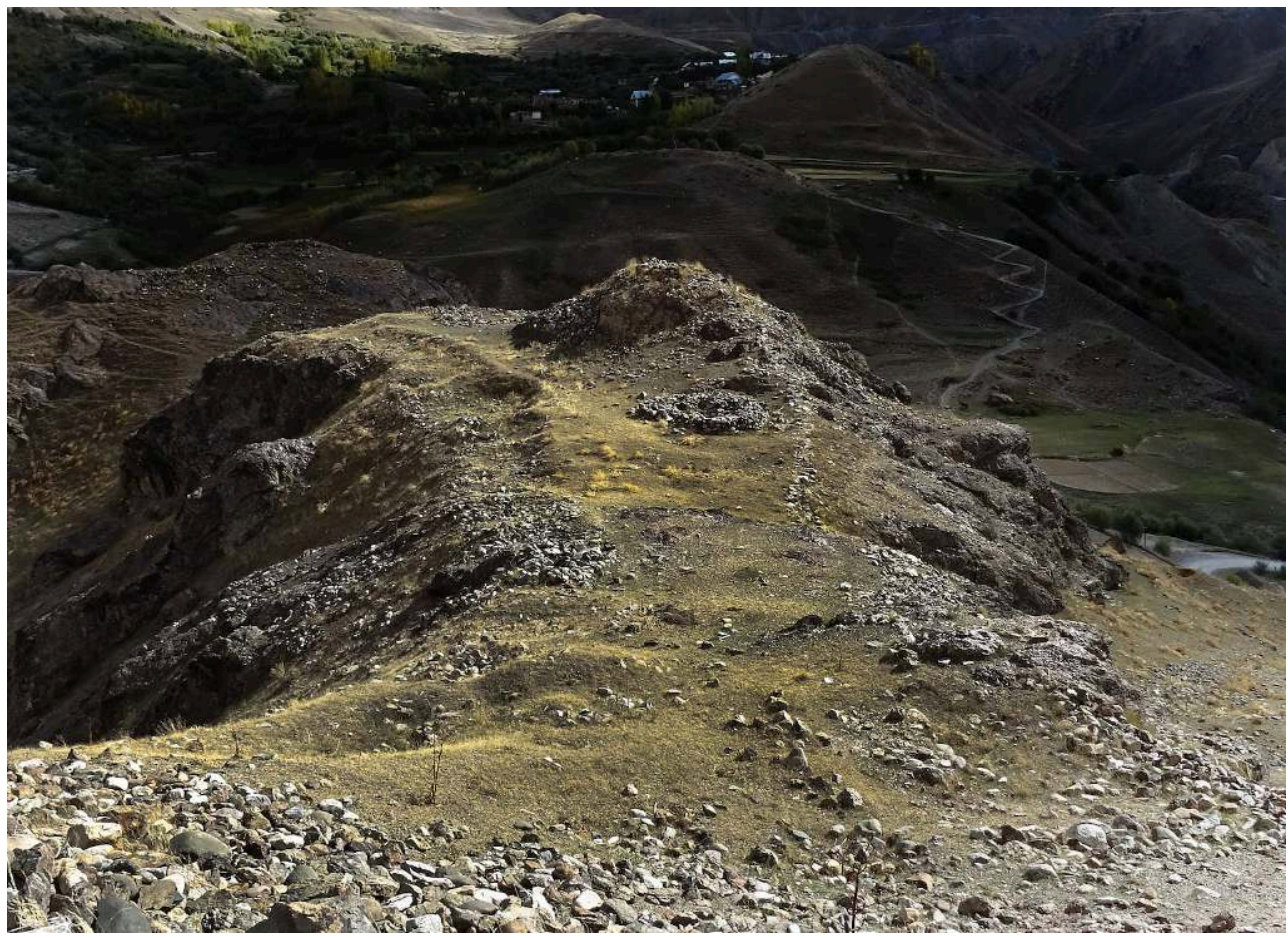

(c) Quentin Devers, 2016

Figure 14. Detailed view of the eastern row of rooms from the south

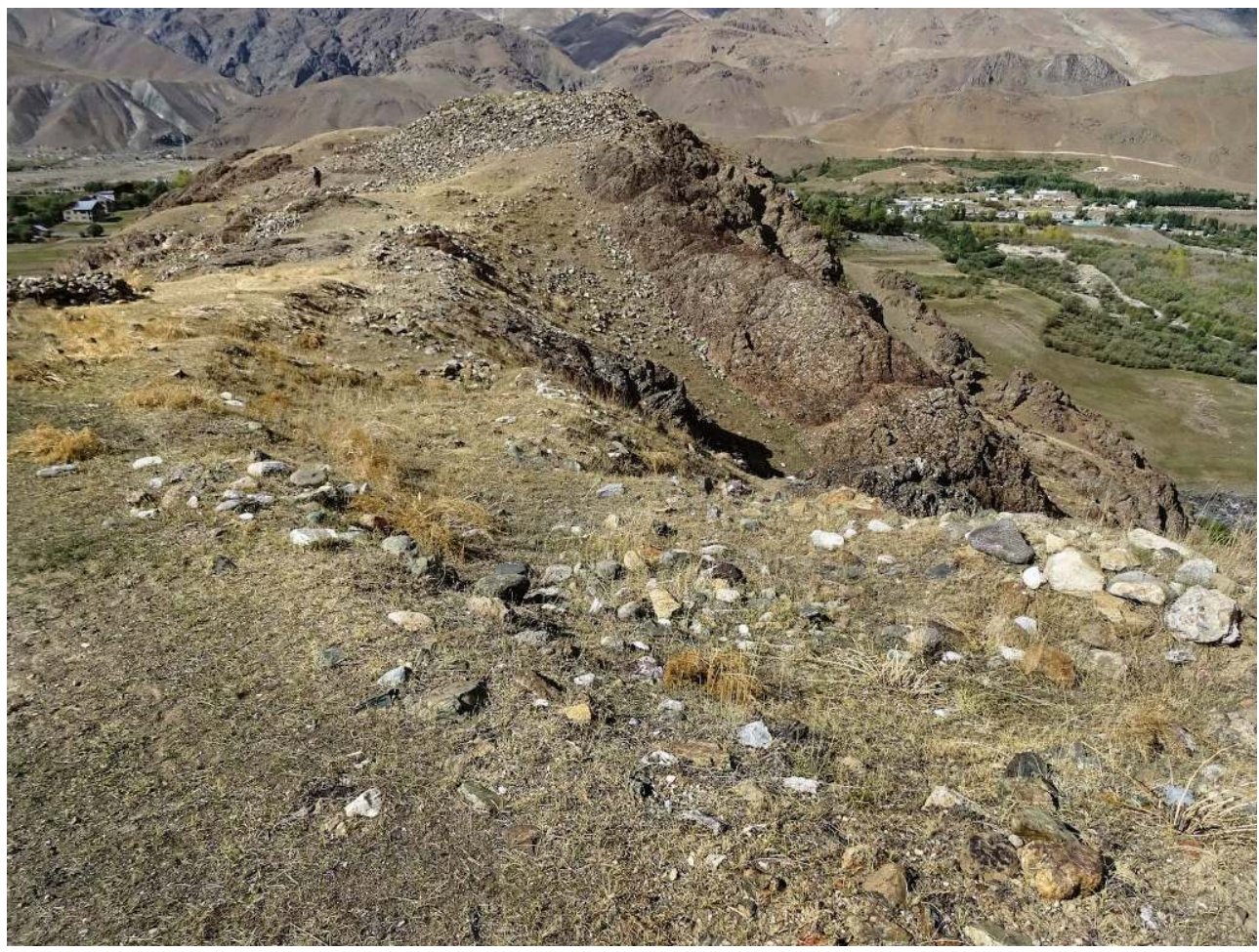

(c) Quentin Devers, 2016

26 Like in Tangol, such a plan suggests a compound that is not a fortified settlement. It should be noted that the nearby Goshan Khar, which also has post-Kushan ceramics 
and similar defences made of shallow trenches, and which is unquestionably a fortified settlement, does not have such a coherent plan of neatly lined peripheral rooms with a central courtyard. Like in Tangol, the plan of the Rgyalmo Khar compound does not reflect the habitual types of residential sites in Ladakh, even within a Kushan or postKushan context.

27 A variety of buildings and miscellaneous structures can be seen outside the topmost compound and within the perimeter set by the defences (fig. 15). Their nature religious, residential, or military - is difficult to conjecture without a more in-depth investigation of the site. The answer to these questions will determine our understanding of the overall nature of Rgyalmo Khar: is it a fortified complex that includes, among other features, a monastic compound? Or is it a fortified monastery, where the defences were specifically built to protect the monastery? Given the Kushan and post-Kushan context of Dras, a fortified monastery would not be unlike what is seen elsewhere in Central Asia at similar periods.

Figure 15. Example of structures found outside the compound and within the defences

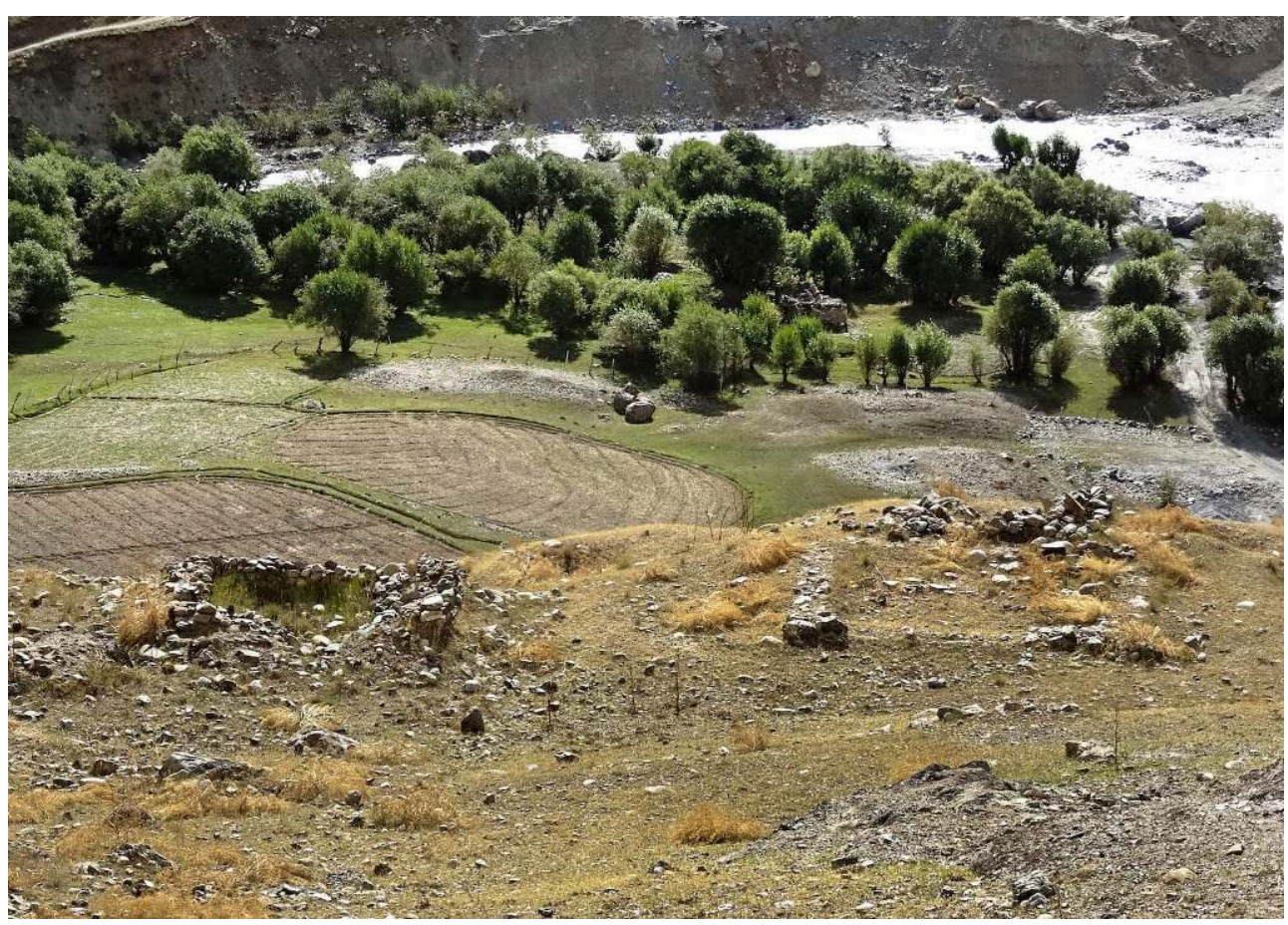

(c) Quentin Devers, 2016

\section{Textual sources}

Francke recorded stories about the fortifications of Dras in the village of Shimsha Kharbu, located in the Dras valley about half way between Dras and the confluence with the Suru river (Francke 1926, pp. 180-181). According to these stories, Goshan Khar was built by the king of Skardo, Ali Sher Khan, in the $16^{\text {th }}$ century. The Lhamochen Khar was then supposedly built by the king of Ladakh, Sar Lhachen. This name is nowhere found in the chronicles of Ladakh or in the chronicles of Guge Purang, but according to the story recorded by Francke he had lived after Ali Sher Khan. 
Finally, the Biru Khar and the Rgyalmo Khar were built by the king of Pashkyum, Rayim Khan. Once again, the name of that king is not found in the documents at our disposal, but according to the tale he lived after king Sar Lhachen. These stories would thus place the constructions of all the fortifications from the $16^{\text {th }}$ century onwards.

As the identification of Kushan and post-Kushan ceramics by Samara Broglia de Moura shows, these sites must have been founded well before the $10^{\text {th }}$ century. These oral stories should thus be taken very cautiously: all the fortifications mentioned by name were built much earlier - in fact, close to a millennium earlier.

\section{Sod: archaeological and historical context}

Let us now turn to the next site, Pikhar, located in Sod. Sod is a side valley of the Wakha stream near its confluence with the Suru river (cf. fig. 3). It includes a vast plateau that overlooks the Kargil basin, which was the main seat of the Kacho dynasty, who supposedly was established in Purig around the $8^{\text {th }}$ century by the somewhat mythical figure Tata Khan coming from Gilgit. Sub-branches of this dynasty were established in Chigtan, Shakhar-Yogma Kharbu and Pashkyum, and these are the first Ladakhi rulers to be known to have converted to Islam in the $16^{\text {th }}$ century ${ }^{17}$.

Whereas Dras and the south Suru valley are naturally connected with Kashmir, Sod is connected with Baltistan and Gilgit. At the northern end of the Sod valley a low pass leads to Batalik, a part of the Indus valley that used to be ruled by Baltistan. To the west, after the confluence of the Suru and Dras rivers, is the Shingo valley, which also was previously under Balti control, as it was ruled by the king of Kharmang. Sod was thus bordered by Balti areas on two sides, on the north and west. It was the dominant force of the Kargil belt opening to the south, and once directly ruled and later had cousin branches ruling over most of the territories to the east (Pashkyum, Chigtan, Shakhar, Yogma Kharbu) - with the exception of Mulbek and Wakha that appear to have been mostly independent from Sod.

Northern Purig (the northern Suru valley, Sod, the Wakha-Mulbek valley, the ChigtanBod Kharbu valley) shelters archaeological remains - rock art, Dard-attributed forts, Kharoshti inscriptions - that are very similar to those in the lower Indus valley leading to Baltistan and Gilgit.

\section{Phikhar. Pikhar (Sod)}


Figure 16. General view of Pikhar from the slope leading to Pasar Khar in the north

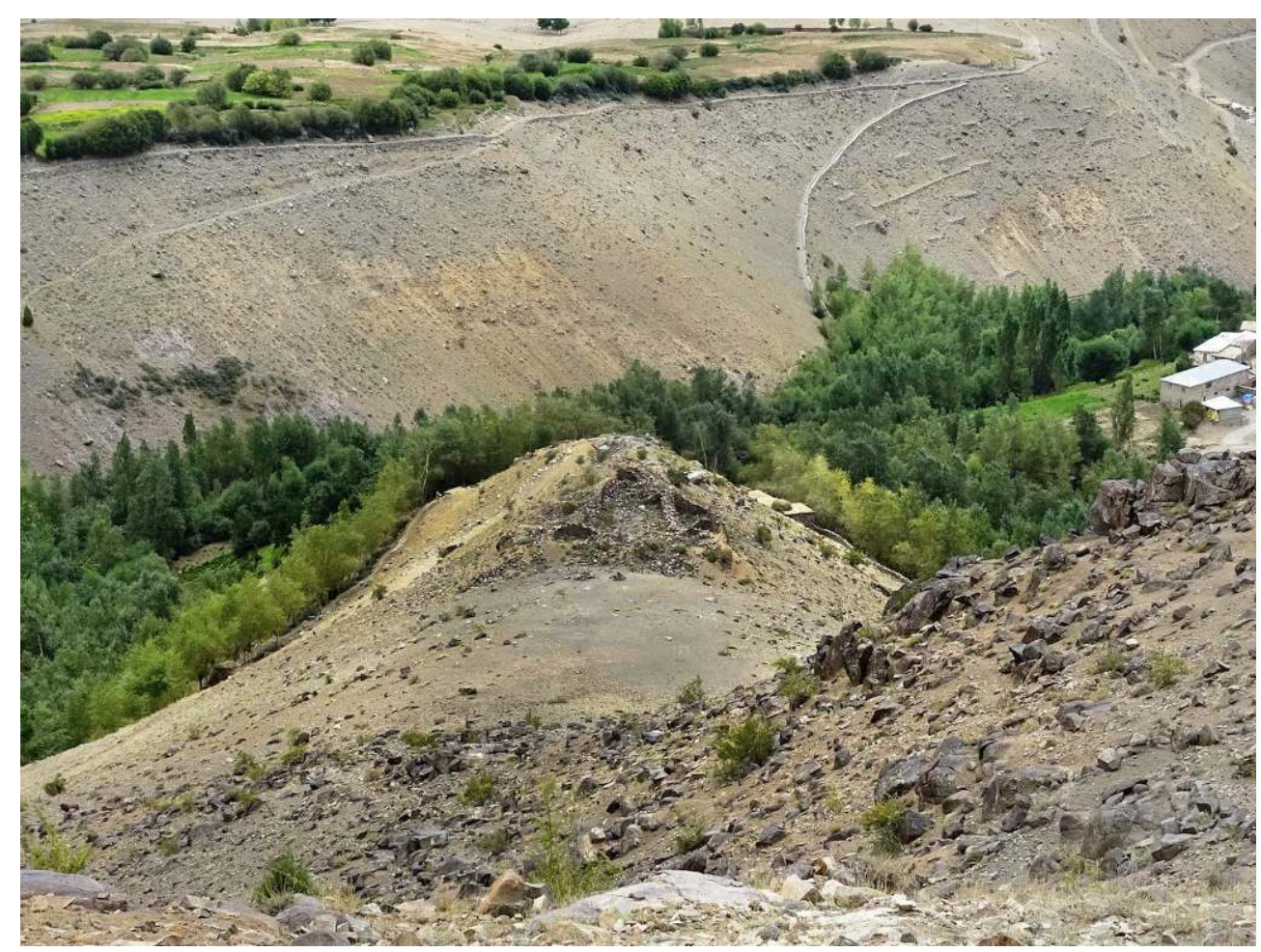

(C) Quentin Devers, 2016

Phikhar is a village next to Yurbaltak, the former capital of the Kacho dynasty. The ruins that interest us, locally known as Pikhar (fig. 16), are located at the foot of the slope that leads to Pasar Khar, the chief fortress of Sod, one of the largest of Ladakh. It consists of a single building, locally said to have been stables for the horses of Pasar Khar. Though Pikhar may have been used as such at a later time, the ruins appear to be of a much earlier date (Pasar Khar may be from the $16^{\text {th }}$ century at the earliest, and perhaps even later), and their design does not match that of stables. 

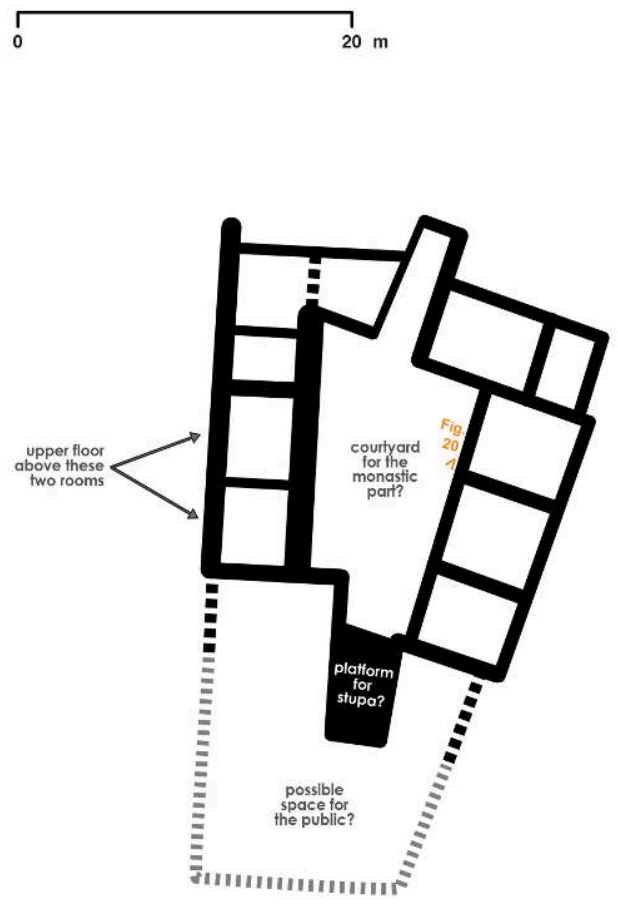

(c) Quentin Devers, 2017

Pikhar consists of a central courtyard framed by a row of three rooms on the eastern and western sides, and a row of four rooms on the northern side (figs 17, 18). The courtyard ends on the south in a tall platform, which, if this was a monastery, could have been the location of a stupa (fig. 19). The foundations of a wall running south from that platform can be seen on the ground, hinting at a secondary space that could have been open to the public. Two of the rooms on the western side had an upper floor, explaining the significant width of the walls there (up to $1,6 \mathrm{~m}$ for the internal wall), which had to bear the load of a second level. The rooms in Pikhar are considerably larger than in Tangol or Rgyalmo Khar. If they were monks' quarters, they would undoubtedly represent cells larger than what was usual for monasteries. However, the overall plan does fit that of a monastery; excavations would thus be needed to properly assess the nature of the site. 
Figure 18. Close up view of Pikhar from the north

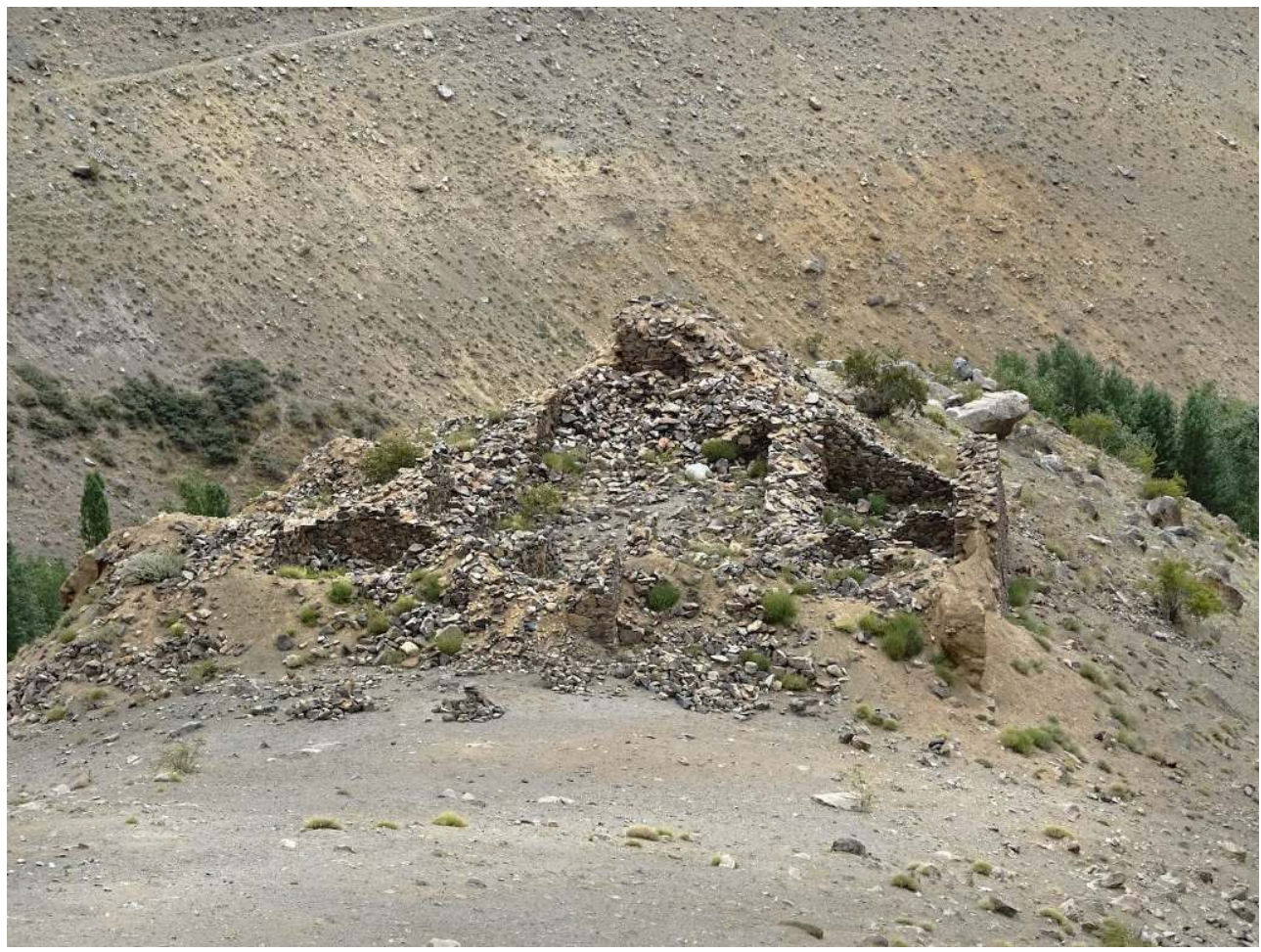

(C) Quentin Devers, 2016

Figure 19. View of the platform from the north

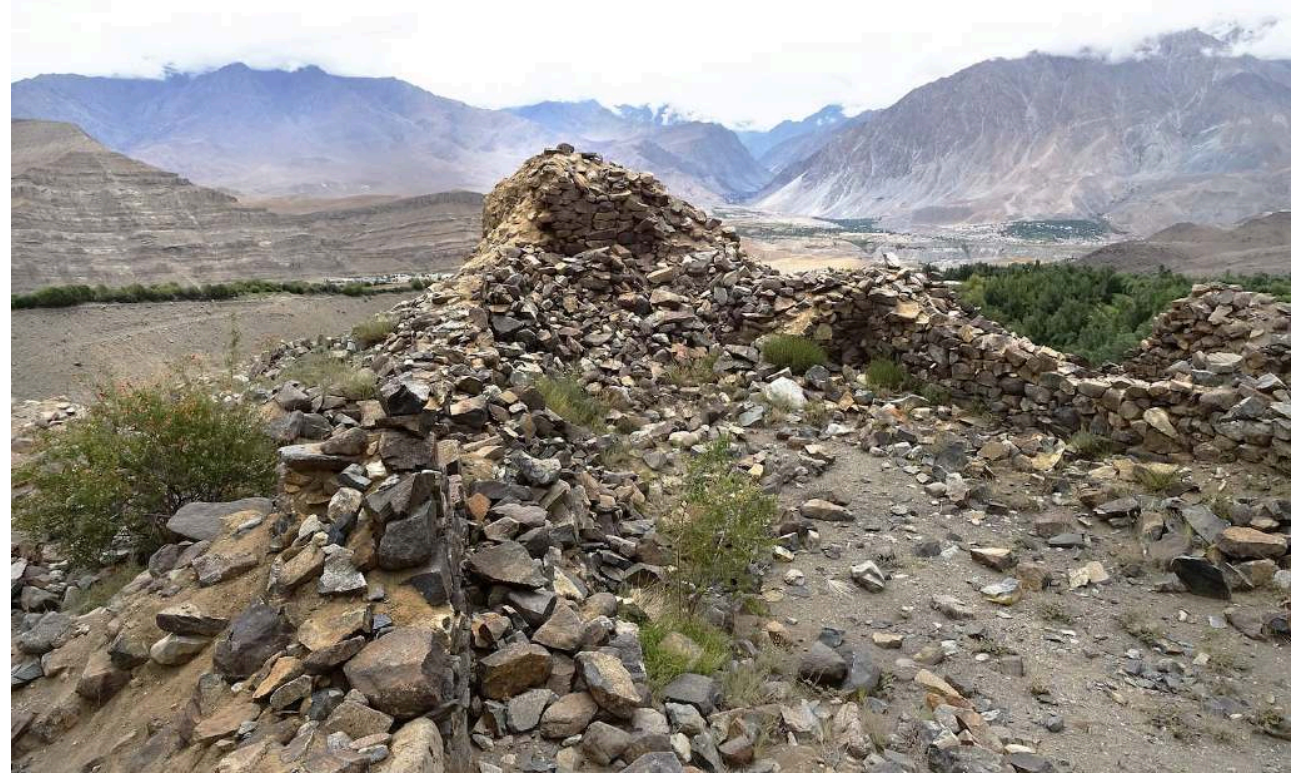

(c) Quentin Devers, 2016 


\section{Sani-Tarungtse: Mon Khar (Zanskar)}

Figure 20. General view of the ruins of Tarungtse from the north: the fortified settlement $(A)$, and the large enclosure (B)

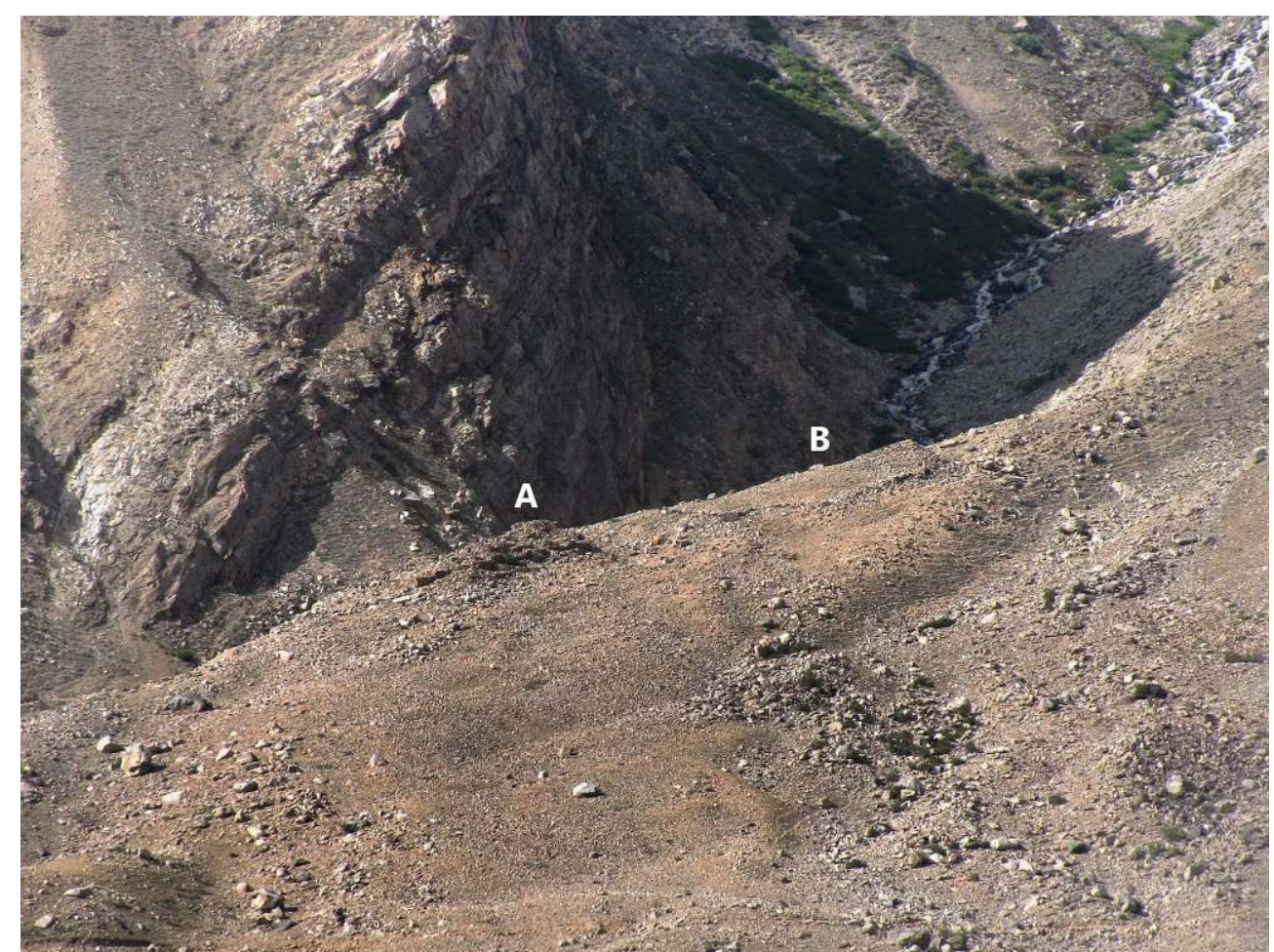

(c) Quentin Devers, 2011

In addition to the sites in Purig, a ruin in Tarungtse (Zanskar) may provide further data on this period. It presents intriguing elements that may explain one of the most debated constructions of Ladakh, the so-called Kanika chorten of Sani, believed to have been built by king Kanishka in the $2^{\text {nd }}$ century CE.

37 Tarungtse is the closest neighbouring village of Sani. The ruins of our concern are set in the slope that dominates the valley, about 2,5 km from Sani monastery. They are locally referred to as Mon Khar, and were already reported by Francke (Francke 1906, p. 650) and again by Howard (Howard 1995, pp. 82-83). They consist of two parts: a small fortified settlement, and above it a large enclosure topped by a ruined building (fig. 20). The settlement presents the usual plan of Mon fortifications, i.e. rooms mainly along the rampart; we can also see that this plan, typical for a fortified settlement, greatly differs from the other sites that we have been reviewing until now (fig. 21). 


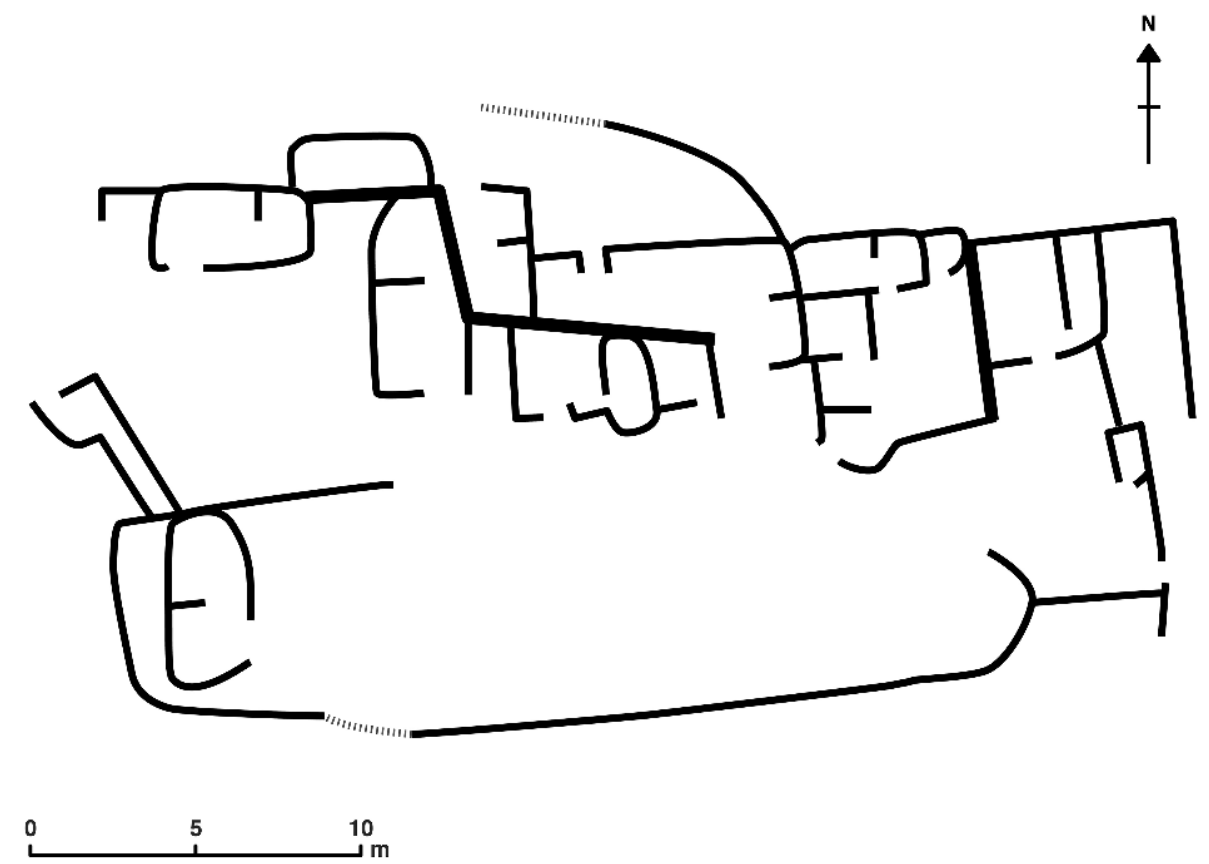

(C) Quentin Devers, 2015

of the large enclosure above the fortified settlement only low courses of large rocks are left. They delineate a vast courtyard bordered by the edge of the topography on its southern side (figs 22-24). A pile of rubble of a former building is seen on the western end (i.e. the upper-most part of the enclosure), and the walls of a several rooms can be distinguished along the enclosure - there may have been more, but the current ruinous condition of the site makes it difficult to assess this. 
Figure 22. View of the large enclosure from the east

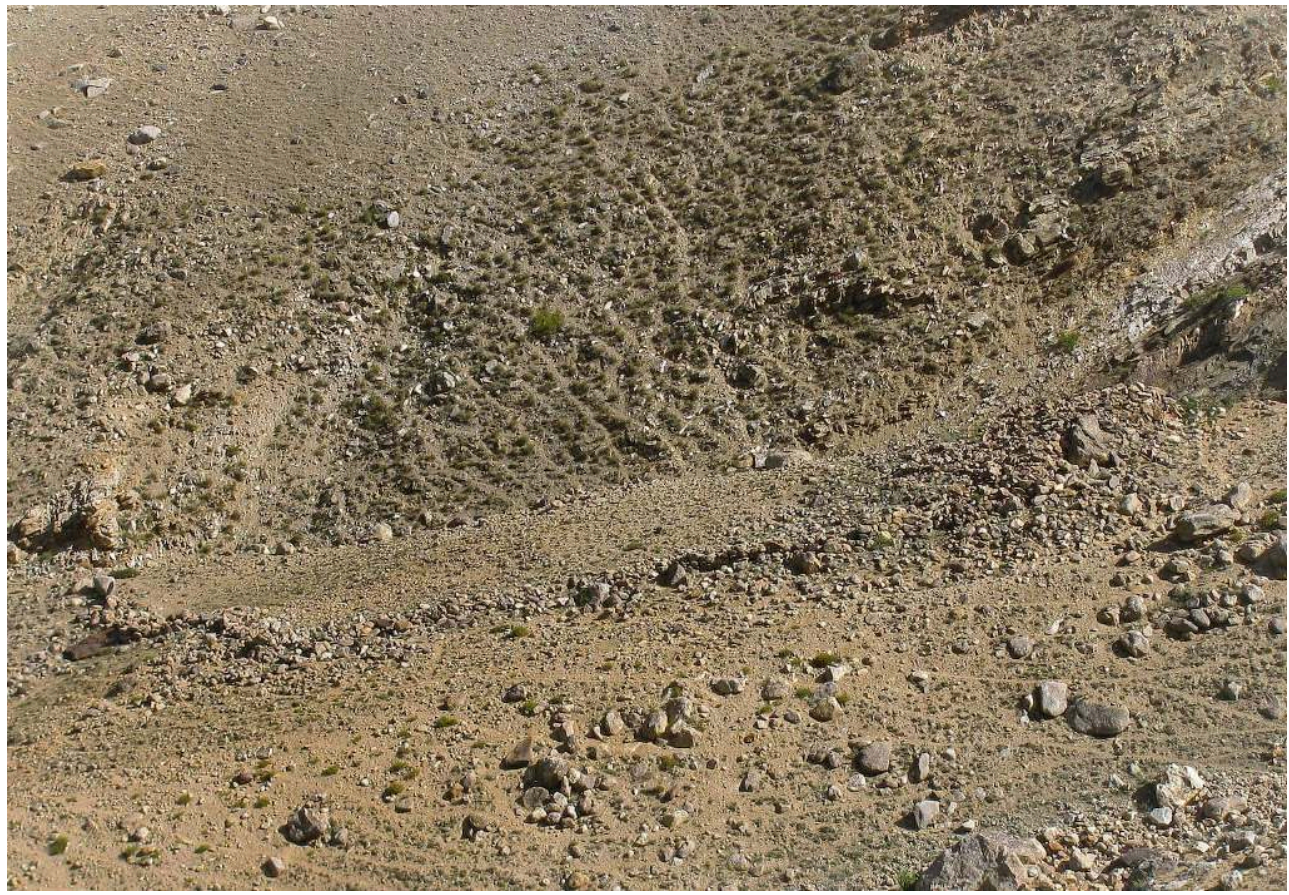

(C) Quentin Devers, 2011

Figure 23. Plan of the enclosure at Tarungtse

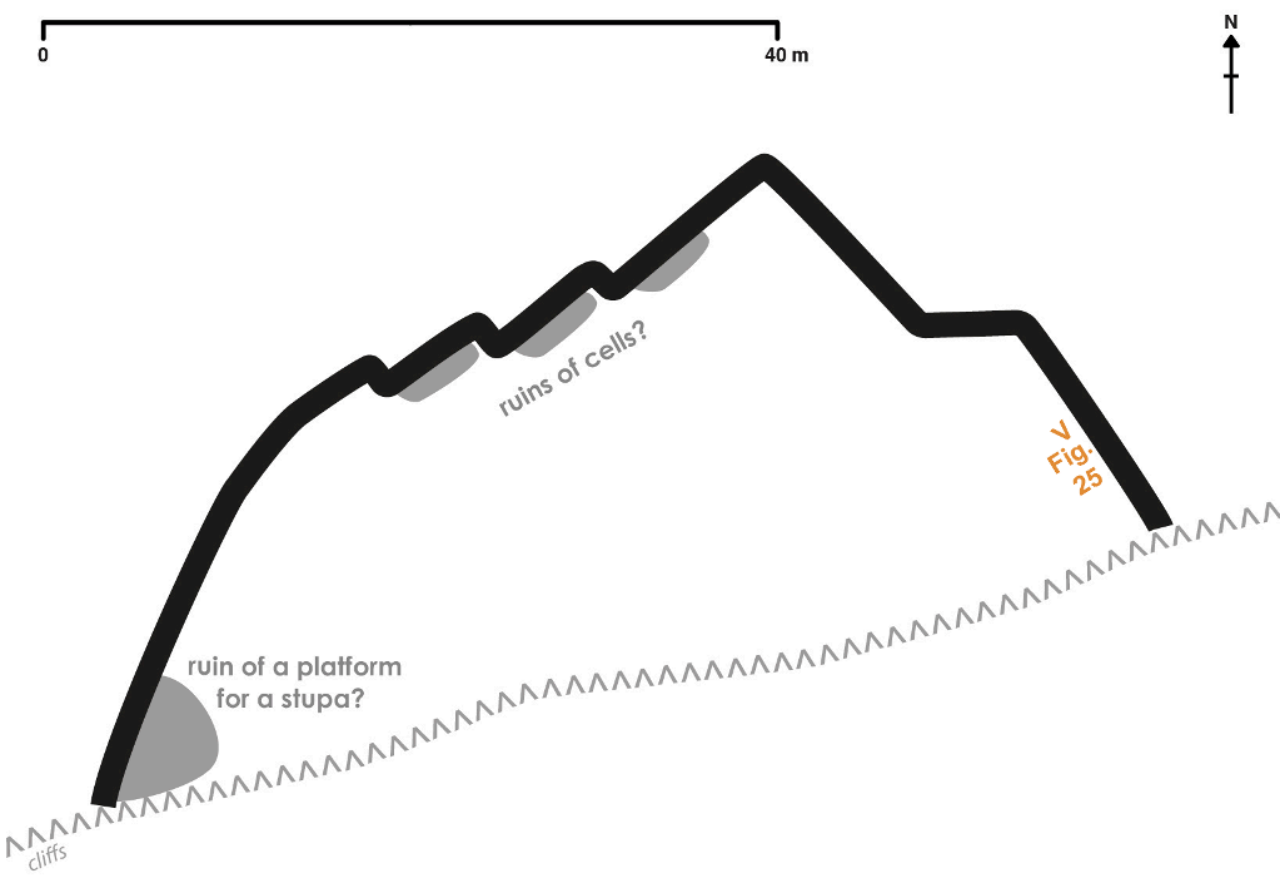

(c) Quentin Devers, 2017 
Figure 24. Detailed view of the remains of the enclosure

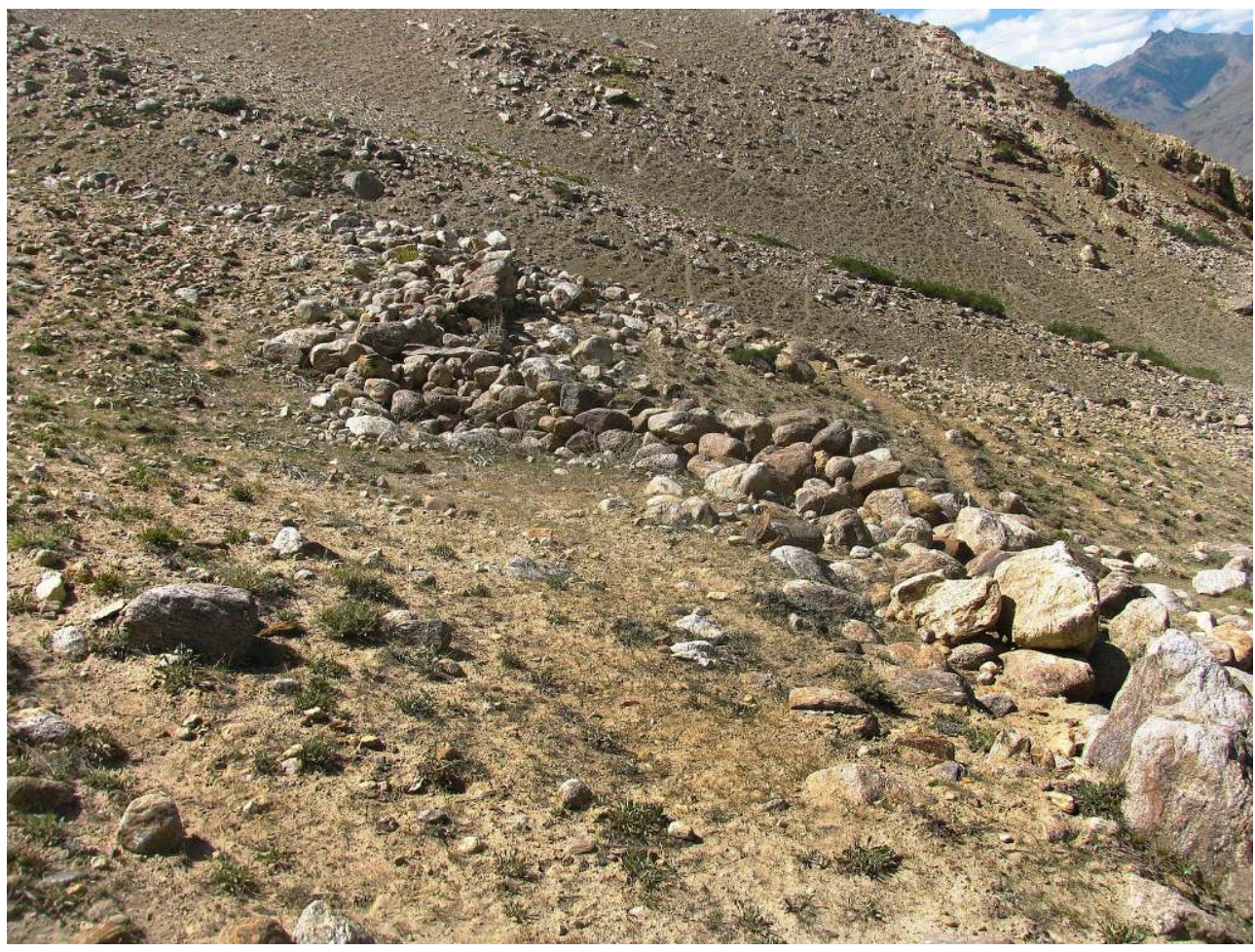

(C) Quentin Devers, 2011

39 Howard interpreted the enclosure and mound of rubble as a fortified perimeter defended by a top tower (Howard 1995, p. 82). Given the data available at the time, it is the interpretation I would also have reached. However, in the light of recent finds, this evaluation may need to be revised. In the summer of 2017, during our joint survey of the area, Samara Broglia de Moura recognised a sherd of red burnished slip, hinting that the site could have Purig or Central Asian influenced ceramics (one would need to find quite more than a single sherd to confirm such a connection). In view of the Kushan and post-Kushan material remains in Dras, and the possible monastic sites in Tangol, Dras and Phikhar, we may have to look at the present ruins differently: the rubble of the top-most tower may have been that of a stupa, from where started an enclosure with cells along it delineating a central courtyard.

Reading these ruins as those of a monastery, at this stage, is of course only tentative. The presence of possible Purig or Central Asian type of ceramics in Zanskar opens up unforeseen perspectives for the study of Zanskar's past, which should lead us to be open to reconsider what we thought we knew.

41 One can also not ignore the strong tradition of a Kanishka stupa in the nearby Sani monastery (fig. 25). This particular stupa, in its present form, cannot date from much before the Ngari period - which is probably the case of the numerous Buddhist carvings in its surroundings as well. Material remains, along with the setting of the monastery in the valley floor can all be perfectly understood within a $10^{\text {th }}$ to $13^{\text {th }}$ century context: nothing in Sani suggests a Kushan or post-Kushan environment. 
Figure 25. The "Kanishka" stupa in Sani

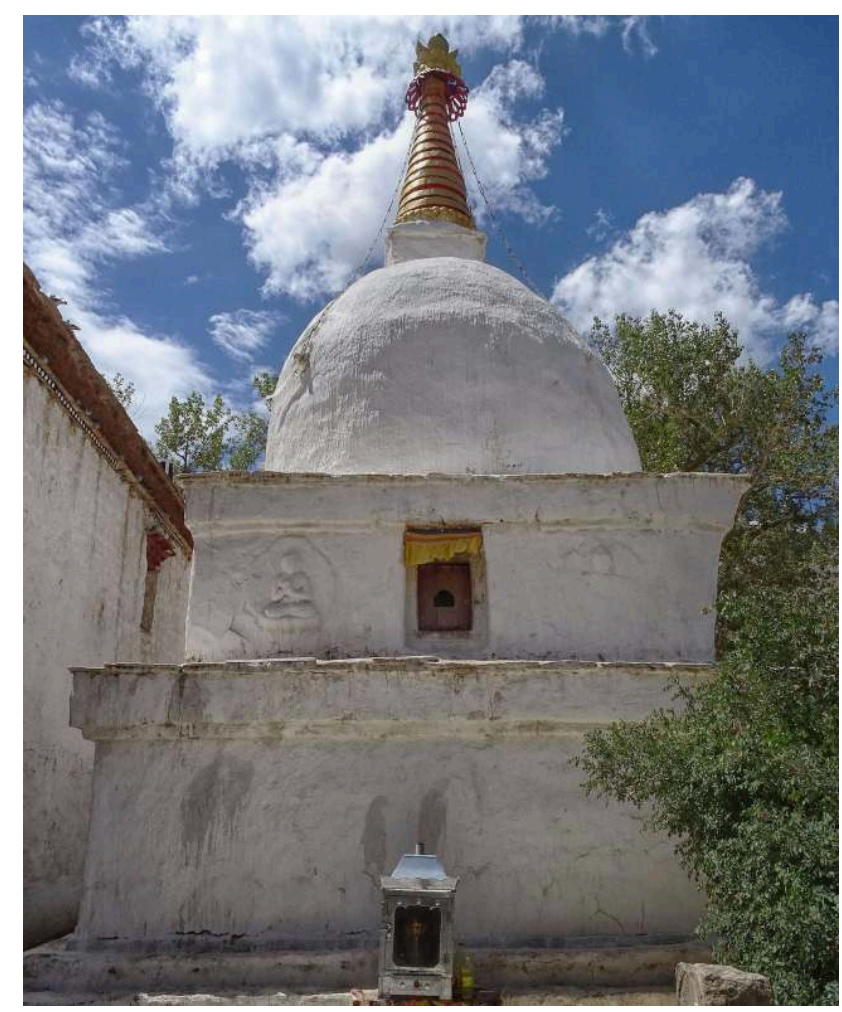

(C) Quentin Devers, 2019

42 A Central Asian-style monastery in Tarungtse could however reconcile this tradition of a Kanishka stupa with the reality of the material remains in both villages. If there was a monastery of Central Asian inspiration in Tarungtse, its stupa could conceivably have been moved to Sani when a newer monastery was established there after Western Tibet took control of the region. Such a stupa, though of more recent built, could have been regarded as the successor of the previous stupa in Tarungtse that the population had been used to see as a landmark in the landscape.

Whether Kanishka actually built this stupa is of little concern, the main element being that the stupa would have predated the Western Tibetan annexation, and would have been from a different tradition of Buddhism. For Ladakhis, Kanishka was probably the most famous ruler from the pre-Tibetan era, and his name is probably to be understood as eponymous for whatever happened before Zanskar came under Tibetan rule. A more familiar example of this association of famous personalities with remains they could not have built are the many temples from the $11^{\text {th }}$ to $15^{\text {th }}$ century period that are attributed to Rinchen Zangpo (958-1055). Associating these temples with his name conveys the idea that they were built before the advent of the Namgyal (Tib. rnam rgyal) dynasty. Thus, labelling a stupa as "Kanishka" could reasonably be understood to indicate that it was built before the rise of Ngari, at a time of Central Asian-influenced Buddhism.

These are of course very hypothetical conjectures, meant at raising the possibility of a phase of Central Asian influence on - and perhaps direct rule of parts of - Zanskar. Like for the previous three sites, far more research and in particular excavations are needed 
in order to assess the nature of this site and to better understand Zanskar's ancient past.

\section{Conclusion}

Ladakh has been inhabited over the centuries by a wide range of populations that included Tibetans as well as Dards, Turks, Mons, Shinas, and Kashmiris - and these are only the groups that have left traces of their presence in written records and oral traditions. The country is at a strategic location that provided it with a near-monopoly on the trade of expensive commodities-gold, pashmina, musk, salt, iron, etc.produced in the Upper Tibetan Plateau. This wealth attracted the attention of all its neighbours, which have carried out regular raids in the region.

Countless fortifications were built throughout history to protect these resources, making Ladakh the area of the Tibetan and Himalayan regions with the highest density of fortified sites - for instance the valley of Chemre has more than one fortification per kilometre. Neighbouring powers were at times ruling over parts of Ladakh. As Thangtong Gyalpo (Tib. thang stong rgyal po) reported, in the $15^{\text {th }}$ century, about sixty villages were settled by Turks (Jamspal 1997, p. 143). As explained earlier, there is evidence that Dras was under Kashmiri rule during parts of its history. In Nubra, the Yabgo dynasty, a branch of which is based in Turtuk, is believed to have come from Western Turkestan. In Purig, the Kacho dynasties are believed to have come from Gilgit. Even the lineage of the Namgyal dynasty includes rulers named Bara and Bagan, hinting at non-Tibetan origins.

This diversity is very tangible in the present religious landscape of Ladakh. Tibetan Buddhism along with Sunni, Shia and Noorbakshia Islam are the most prominent traditions currently practiced, which perfectly summarize the influences that Ladakh's main neighbours - Tibet, Kashmir, the Tarim Basin and the Pamir corridor - have had on the region. When Ladakh was a Buddhist country, Purig became the gateway for Islam, a religion coming from the Pamir corridor and from Kashmir. Earlier, when Ladakh was following animistic religions, Purig may conceivably have been the gateway for Buddhism, coming from the same regions of the Pamir corridor and Kashmir.

The sites of Tangol, Dras and Sod may represent some of the monasteries that may have been built during that period. All follow the same plan of rows of rooms arranged around a central courtyard with a tall platform, where a stupa could have been placed. All are oriented north to south, with the platforms for these possible stupas on the southern end. At the site in Dras, post-Kushan ceramics was identified, and at Tarungtse in Zanskar the ruins are found in the surroundings of a monastery where a typical Ngari-period stupa is traditionally associated with Kanishka. None of these sites follow the patterns of defensive architecture observed in any of the other $370+$ fortifications known so far in Ladakh. And these ruins differ considerably from the later monasteries of the Second Spread of Buddhism - which are based on temples and are mostly devoid of habitations, like the complex in Nyarma.

More research is needed to assess the nature and chronology of these sites; in fact steps are already being taken to begin proper excavations there. More research is also needed to identify other possible sites belonging to this period of Buddhism - Chemre, Phey, Sabu and Nyarma (Upper Ladakh) as well as Digur (Nubra) would for instance be strong candidates. Across these sites, one finds a number of elements (architecture, 
layout, use of topography, etc.) that greatly differ from those observed at sites derived from the First and Second Diffusions. Ladakh was part of the Kashmiri and Central Asian worlds just as much as it was part of the Tibetan world. It should therefore not be a surprise that the history of Buddhism in the region reflects this ancient heritage, with a Central Asian and Kashmiri component

\section{Acknowledgements}

50 I am very thankful to Samara Broglia de Moura for the invaluable information that she generously shared with me for the writing of this article. Her identification of Kushan and post-Kushan ceramics represents an amazing breakthrough, establishing a solid timeframe for a set of sites and confirming the material influence from the North-West that I was only able to conjecture until then. I am also incredibly thankful for the wonderful collaboration with INTACH, made possible by Kacho Mumtaz Khan and Vijaya Amujure.

51 I acknowledge advice, suggestions and comments from Samara Broglia de Moura, Nils Martin, Sonam Spalzin, Heinrich Pöll and Gerald Kozicz. Any error of fact or interpretation is my responsibility only. My fieldwork was facilitated by the precious help provided by Kacho Sikundar Khan, Hassan Khan, Kacho Shamim Khan, Kacho Ishtyaq Khan, Samara Broglia de Moura, Nils Martin, Utsavi Singh, and Vedant Rastogi. All illustrations are by the author unless stated otherwise.

\section{BIBLIOGRAPHY}

Alexander, A. 2016 Alchi Tsatsapuri. Notes on the history of an Early monument, in R. Linrothe \& H. Poell (eds), Visible Heritage. Essays on the Art and Architecture of Greater Ladakh (Delhi, Studio Orientalia), pp. 1-22.

Bruneau, L. 2013 Rapport Préliminaire, Campagne 2013 [online, URL: http://www.mafil.org/wpcontent/uploads/2016/03/MAFIL-rapport-campagne-2013-web-FR.pdf, accessed 29 July 2019].

Devers, Q. in press, Historical sites of Zanskar (New Delhi, Indian National Trust for Art and Cultural Heritage).

Devers, Q. 2018 Historical Sites of Purig, Kargil, Ladakh, Jammu \& Kashmir (New Delhi, Indian National Trust for Art and Cultural Heritage).

Elias, N. \& E. D. Ross [1898] 2009 The Tarikh-I-Rashidi of Mirza Muhammad Haidar Dughlat. A History of the Moghuls of Central Asia (Srinagar, Karakoram Books) [online, URL: http://archive.org/details/ TheTarikh-i-rashidi, accessed 29 July 2019]

Francke, A. H. 1906 Kleine archäologische Erträge einer Missionsreise nach Zangskar in Westtibet, Zeitschrift der Deutschen Morgenländischen Gesellschaft 60, pp. 645-661.

1907 Historische Dokumente von Khalatse in West-Tibet (Ladakh), Zeitschrift der Deutschen Morgenländischen Gesellschaft 61, pp. 583-614.

1914 Antiquities of Indian Tibet, part 1, Personal Narrative (Calcutta, Government Printing, 
Archaeological Survey of India New Imperial Series 48).

1926 Antiquities of Indian Tibet, part 2, The Chronicles of Ladakh and Minor Chronicles (Calcutta, Government Printing, Archaeological Survey of India New Imperial Series 50).

Ganhar, J. N. \& P. N. Ganhar 1956 Buddhism in Kashmir and Ladakh (New Delhi, P. N. Ganhar).

Goepper, R. 2003 More evidence for dating the Sumtsek in Alchi and its relations with Kashmir, in I. Kreide-Damani (ed.), Dating Tibetan Ar. Essays on the Possibilities and Impossibilities of Chronology from the Lempertz Symposium, Cologne (Wiesbaden, Reichert Verlag), pp. 15-24.

Howard, N. 1995 The fortified places of Zanskar, in H. Osmaston \& P. Denwood (eds), Recent Researches on Ladakh 4 \& 5. Proceedings of the Fourth and Fifth International Colloquia on Ladakh (London, School of Oriental and African Studies, University of London), pp. 79-99.

Jamspal, L. 1997 The five Royal Patrons and three Maitreya, in H. Osmaston \& N. Tsering (eds), Recent Research on Ladakh. Proceedings of the Sixth International Colloquium on Ladakh, Leh 1993 (New Delhi, Motilal Banarsidass), pp. 139-156.

Martin, N. 2015 An Overview of the Wall-Paintings and Inscriptions in the Old Temple of Mulbek, paper presented at the $17^{\text {th }}$ Colloquium of the International Association of Ladakh Studies, Kargil, 28 July 2015.

Moorcroft, W. \& G. Trebeck 1841 Travels in the Himalayan Provinces of Hindustan and the Panjab; in Ladakh and Kashmir; in Peshawar, Kabul, Kunduz, and Bokhara; by Mr. William Moorcroft and Mr. George Trebeck, from 1819 to 1825, vol. 2 (London, John Murray).

Petech, L. 1977 The Kingdom of Ladakh, c.950-1842 A.D. (Roma, Istituto italiano per il Medio ed Estremo Oriente, Serie Orientale Roma 51).

Sander, L. 1994 A graffito with the quintessence of Buddhist doctrine from Ladakh, in N. Balbir \& J. K. Bautze (eds), Festschrift Klaus Bruhn zur Vollendung des 65. Lebensjahres (Reinbek, Verlag für Orientalistische Fachpublikationen), pp. 561-570.

Stein, M. A. 1900 Kalhana's Rājataranigin. A Chronicle of the Kings of Kaśmìr, vol. 1 (Westminster, Archibald Constable and Company).

Vernier, M. \& L. Bruneau 2016 Report: Fieldwork 2015 [online, URL: http://www.mafil.org/wpcontent/uploads/2016/06/MAFIL-2015-report-online.pdf, accessed 29 July 2019].

Vernier, M. \& Q. Devers 2014 The uncommon history of Markha Chorten, Ladakh, Revue d'Études Tibétaines 30, pp. 199-218.

\section{NOTES}

1. In this paper, Wylie spellings are not provided for place names. For most places in Ladakh, Wylie spellings are either unknown or, at best, debated by villagers. Furthermore, it needs to be recalled that multiple ethnic groups coexisted and succeeded one another in the region. Not all toponyms are therefore of Tibetan origin. As a result, providing artificial Wylie spelling can only create confusion about the toponymy and etymology of these place names.

2. A sample taken from the platform yielded a date from 695 to 937 , with maximum probability of 710 to 745 or 764 to 894 , i.e. from the early $8^{\text {th }}$ to late $9^{\text {th }}$ century. Another sample taken from the central pole yielded a date from 425 to 579 (Vernier \& Bruneau 2016, p. 22), but this date cannot be retained.

As a matter of fact, samples taken from large pieces of wood in the arid and mostly treeless environment of Ladakh and Upper Tibet have proven utterly unreliable. A sample taken from a 
column of one of the temples of the Tsatsapuri complex in Alchi thus yielded a $90 \%$ probability result of 1152 to 1275 CE (Alexander 2016, p. 21), whereas the wall paintings can securely be dated to the mid to late $14^{\text {th }}$ century as Nils Martin has shown (Martin, forthcoming article). Another example is the painted chorten of Markha, datable on stylistic grounds to the $15^{\text {th }}$ or $16^{\text {th }}$ century, and which contains a wooden column from the $11^{\text {th }}$ or $12^{\text {th }}$ century (Vernier \& Devers 2014, p. 207). Major inconsistencies between the date of a structure and the $\mathrm{C}^{14}$-dates of large pieces of wood are a common occurrence in Ladakh. Samples from structural elements such as columns and timbers cannot be trusted, as large pieces of wood are regularly reused over long periods of time. Only samples taken from small pieces of wood, where reuse can be positively excluded, can be used for scientific dating.

3. Devers 2018, pp. 9-10, 98, 153, 169.

4. Devers, in press.

5. Apart from the district capital Kargil, where all Muslim communities as well as Buddhists are present.

6. Maliks were Kashmiri officers who held hereditary control of the passes into Kashmir and were granted villages for their tenure (cf. Moorcroft \& Trebeck 1841, p. 41).

7. There are only very few other inscriptions in Sarada or proto-Sarada in Ladakh, none of which adorn Buddhist carvings. One in proto-Sarada is in the left niche of the Sumtsek temple in Alchi (Goepper 2003, p. 22). Another in proto-Sarada is inscribed inside the carving of a chorten in Tangtse (Sander 1994). Two inscriptions, both now gone, were documented on a rock in Khaltse by Francke (Francke 1907, p. 596), and another on the walls of a (now lost) temple in Sgang near Chigtan (Francke 1914, p. 100). Finally, in 2016 I documented a new inscription written in what looks like Sarada on a rock in Kharool, a village situated at the mouth of the valley of Dras. It should be noted that Francke also reported on several occasions to have seen Sarada script on small moulded figures made of the ashes of the deceased (tsatsas, Tib. tsha tsha) in various places in Ladakh.

8. In this paper the term "Lower Indus" always refers to the lower Indus valley of Ladakh, downstream of the confluence with the Zanskar river near Nimu.

9. Examples are Kartse Khar, or "the fort of the white peak", in Kartse; Bragnag Khar, or "the fort of the dark -rock", in Khaltse; Tsemo Khar, or the "the fort of the female peak", in Leh, Bod Kharbu and Shera; Rigo Khar, or "the fort of the mountain head", in Nye near Basgo; and Tselam Khar, or "the fort of the mountain path", in Phyang.

10. One such example is Sumbrang Khar, or "the fort of the three valleys", in Wakha.

11. For instance, the Lhame Khar, or "fort of the deity", in Khyungyam Do is so named as it was built overnight by a deity; Ramaruchig Khar, or "fort of a red goat", in Takkar because of a story about a goat once stuck inside the fort; Gyalmo Hu Khar, or "the fort of the queen", in Tangso because a queen is said to have once worn countless different dresses during a siege to make the assailants believe that the empty fort was defended by a large force.

12. Such names include Mon Khar, Brogpai Khar, Hor Khar or Balti Khar; they are encountered in every corner of Ladakh.

13. We find a Mentok Khar in Matho, Sakti, Garkon and Pashkyum.

14. Locally, the name "Mon" is used in Ladakh to designate past populations believed to have come from the southern side of the Himalayas.

15. This was pointed out to me by Samara Broglia de Moura during our joint survey of the site.

16. In the context of this paper this means a form of Buddhism that is not the result of the First or Second Diffusion.

17. From his mixed Buddhist and Muslim name, it is safe to assume that Tsering Malig, the ruler of Chigtan belonging to the Kacho lineage of Sod, had converted to Islam. Tsering Malig was at the centre of a conflict between Ladakh and Baltistan at the beginning of the $17^{\text {th }}$ century (Petech 1977, pp. 33-34), meaning that he was already alive at the end of the $16^{\text {th }}$ century. Earlier in the 
century, Mirza Haidar, during his campaigns in Ladakh between 1532 and 1535, joined forces with the king of Sod, Tangi Sakab, in order to loot the Suru valley. Their raiding party was however repelled by the ruler of Suru, Baghan, who was mortally wounded during the defence of his kingdom. Mirza Haidar's men handed Baghan over to a group of Muslims, who appear to have been the troops of Tangi Sakab; this suggests that Sod may have already converted at least in part to Islam at that time (Elias \& Ross 2009, pp. 405-406).

\section{ABSTRACTS}

This paper explores the question of the introduction of Buddhism to Ladakh by looking at a series of recently documented ruins that appear to be monasteries from before the First Diffusion.

Cet article explore la question de l'introduction du bouddhisme au Ladakh à travers l'étude d'une série de ruines récemment documentées qui ressemblent à des monastères datant d'avant la Première Diffusion.

\section{INDEX}

Keywords: archaeology, Buddhism, Ladakh, Purig, Zangskar, Kargil

Mots-clés: archéologie, bouddhisme, Ladakh, Purig, Zangskar, Kargil

\section{AUTHOR}

\section{QUENTIN DEVERS}

Quentin Devers is a researcher at the French National Centre for Scientific Research (CNRS), in the Research Centre for East Asian Civilisations (CRCAO, Paris). He has been conducting extensive fieldwork in Ladakh since 2009, and has surveyed over a thousand heritage sites. qdevers@gmail.com 